\title{
Evaluation of the Profitability of Using Solar Collectors in Single-Family Housing Industry - The Case of Poland
}

Mariusz Niekurzak ( $\sim$ mniekurz@zarz.agh.edu.pl )

AGH University of Science and Technology https://orcid.org/0000-0003-4966-8389

Ewa Kubińska-Jabcoń

AGH: Akademia Gorniczo-Hutnicza imienia Stanislawa Staszica w Krakowie

\section{Original article}

Keywords: renewable energy sources, solar collectors, thermal energy, solar energy

Posted Date: January 19th, 2021

DOI: https://doi.org/10.21203/rs.3.rs-148682/v1

License: (c) (1) This work is licensed under a Creative Commons Attribution 4.0 International License.

Read Full License 


\title{
Evaluation of the Profitability of Using Solar Collectors in Single-Family Housing Industry - The Case of Poland
}

\author{
Mariusz Niekurzak1,*, Ewa Kubińska-Jabcoń ${ }^{1}$ \\ 1 Faculty of Management, AGH University of Science and Technology, Gramatyka 10, 30-059 Krakow, Poland \\ * Correspondence: mniekurz@zarz.agh.edu.pl
}

Background: The growing consumption is what drives the development of unsustainable energy and material-intensive production technologies that emit large quantities of pollutants into the atmosphere, water and land. Obtaining green energy allows to reduce the interference with the environment and, consequently, fits into a sustainable energy development strategy. In order to achieve the emission targets set by the EU for Poland, it is necessary to prioritise the development of (RES - Renewable Energy Sources) technologies within the energy sector.

Methods: The purpose of the study is to present the results of the research relating to the profitability of solar collectors investment for single-family houses in Poland. The research was presented on the basis of the legal conditions applicable to micro installations in the light of the amendment of the RES Act and the impact of these amendments on the aspects of the profitability of such investment was determined.

Results: On the basis of the constructed economic model used to assess the profitability of increasing the area of solar collectors, it has been shown that an operating installation will bring measurable economic benefits in the form of reduction in the amount of energy purchased from the current supplier and environmental benefits in the form of reduction of carbon dioxide emissions to the atmosphere. The obtained results have been generalised, which allows to use them in the process of selecting the size of collector area for similar installations.

Conclusion: The cost-effectiveness analysis carried out in respect of a detached house allowed to demonstrate that this project is fully justified. Furthermore, pursuant to the Renewable Energy Sources Act in force in Poland, treating a small entrepreneur as a prosumer who may generally take advantage of favourable conditions for discounting the produced energy leads to very favourable possibilities of settling electricity. Considering an entrepreneur as a prosumer who may use one-off depreciation of a solar collectors installation as a fixed asset and request for VAT refund is what makes such an investment very attractive in financial terms and makes it difficult to find a safe investment alternative characterised by such a high rate of return.

Keywords: renewable energy sources, solar collectors, thermal energy, solar energy

\section{Introduction}

Environmental pollution, depletion of conventional fuels and global warming seem to be among the main problems encountered by the humanity in the 21st century. The fossil fuel energy production process is largely responsible for anthropogenic greenhouse gas emissions, acid rain and other negative 
health and environmental impacts. Furthermore, in 2018, the consumption of electricity in Poland increased by ca. $1.7 \%$ and thus reached the highest level in the history of our country - 171 TWh [1]. At the same time, domestic production reached ca. $165.3 \mathrm{TWh}$, which is a reduction by $0.3 \%$ as compared with the previous year. As a result of these processes, we had to import 5.7 TWh of energy from Ukraine, Sweden and Lithuania. One of the solutions aimed at improving the level of Poland's energy security and reducing its harmful impact on the environment is to make wider use of alternative energy sources. Due to the support of government programmes, the solar collectors sector may be one of the fastest growing (RES - Renewable Energy Sources) sectors in Poland and worldwide. The solar collectors market in Poland has a huge but so far highly untapped development potential. According to forecasts, the solar energy industry will become the largest producer of renewable energy not only in Poland but also in the world, larger than producers of water and wind energy; consequently, the solar energy industry will produce more electricity than all nuclear power plants in the world.

\section{Renewable energy sources and the European Union}

The development of (RES - Renewable Energy Sources) and, consequently, the battle against climate change are some of the most important topics of the last few years. Such actions are considered a priority in the energy policy of the Member States of the European Union, which have set themselves ambitious targets for both reducing greenhouse gas emissions and the share of renewable energy. Pursuant to Directive 2009/28/EC [2], 28 Member States are required to ensure a certain share of energy from renewable sources in gross final energy consumption in 2020. It is the EU's goal to achieve in the European Community 20\% of energy from renewable sources by the end of 2020 and at least $32 \%$ by $2030[2,3]$. What should be emphasised here is that each country has its own objectives, which have been set at levels that are achievable. The span is considerable, since Malta is to reach only $10 \%$, while Sweden as much as $49 \%$ [3]. In Poland, on the other hand, the share of energy from renewable sources in gross final energy consumption was set at $15 \%$. Poland, like Bulgaria, the Czech Republic or Romania, is still strongly dependent on lignite energy and has not yet developed a specific plan aimed at changing this situation [4]. However, thanks to the considerable reduction in the cost of solar energy, solar collectors are increasingly being chosen by both households and the private sector as an investment that allows to make significant savings. In recent years, however, the development of RES, and in particular the solar collectors technology, has been largely dependent on state policies and the introduced support solutions, such as, for example, "Mój Prąd", "Czyste Powietrze" or "Energia Plus" [5,6]. The purpose of these programmes was to enable Poland to achieve the EU target of $15 \%$ share of RES. In Poland, we have recently observed a real demand for solar energy. The solar collectors market is the fastest-growing market of all RES sectors. In 2019, Poland achieved an increase in new capacity of ca. 0.9 GW and was ranked among the top five of all Member States of the European Union with a 5.5\% capacity increase [7]. After Spain and Germany, the largest increase in the installed solar collectors capacity in the European Union is to be recorded this year by the Netherlands (2.5 GW) and France (1.1 GW) [8]. Figure 1 shows annual increases in the new capacity in EU countries.

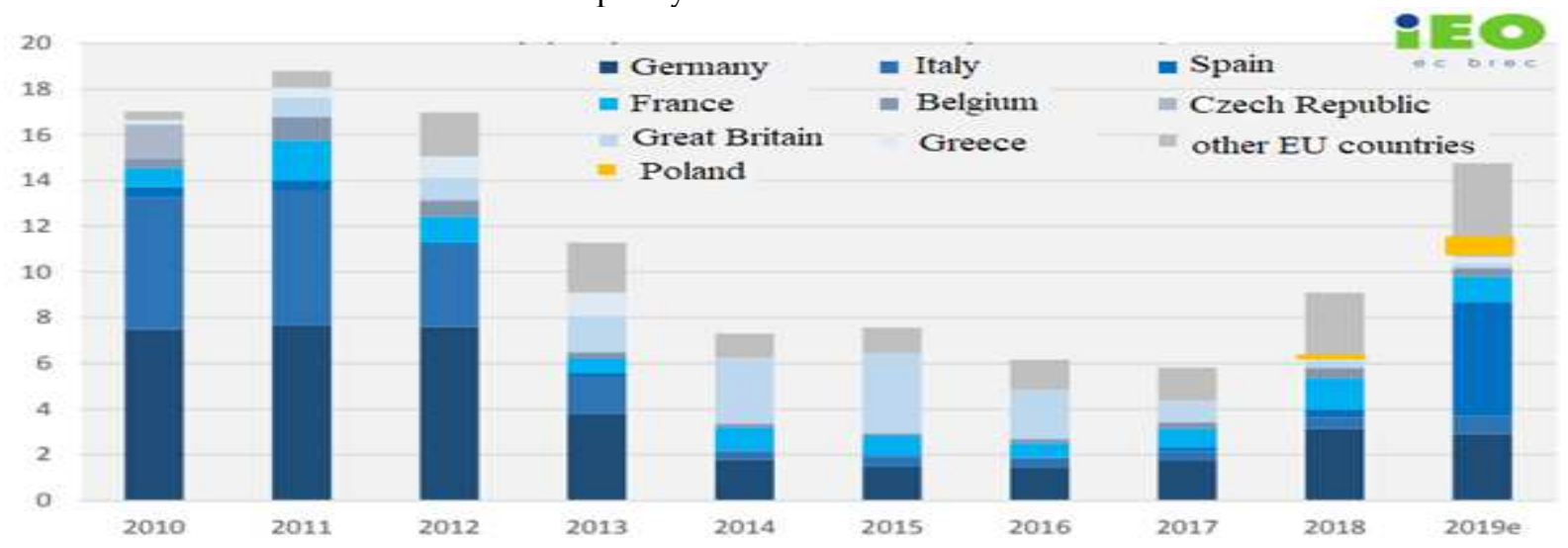

Figure 1. Annual increase in the new solar collectors capacity in EU countries [9]. 
Taking into account the current and real investments in progress and the trends, in 2021 Poland may improve its 5 th place in terms of the annual increase in the new solar collectors capacity. What affects this value is the installations that have already been constructed and all those that are yet to be constructed, i.e. projects from the second RES auction that have not yet been completed, some of the projects from the third RES auction, new installations at business and individual prosumers. As a result, the accumulated capacity of solar collectors in Poland at the end of 2020 may reach $2.5 \mathrm{GW}$, which would allow Poland to join the top $10 \mathrm{EU}$ countries in terms of the accumulated solar collectors capacity [10]. The undisputed leader in terms of the installed capacity in the European solar collectors industry is Germany, which already has solar collectors power stations of the total capacity exceeding $50 \mathrm{GW}$, and the current number of German investments in solar collectors does not decrease. In the first four months of 2020 alone, our western neighbours installed 1.48 GW. Europe's second largest solar collectors market is Italy, where the total capacity of solar collectors power stations already exceeds $21 \mathrm{GW}$, but it has not been growing so fast recently. The capacity of the solar collectors power stations built in Italy last year was lower than in Poland (ca. 737 MW, which was the best result of the Italian solar collectors sector in the last 6 years). The third largest market in Europe as regards solar collectors capacity is the United Kingdom, but in recent years solar collectors investments have slowed down following the phasing out of support schemes in the form of feed-in tariffs and green certificates and due to the lack of an alternative, for example auctions for solar collectors. Currently, the United Kingdom has solar collectors power stations of the capacity of ca. $13.3 \mathrm{GW}$, which increased last year by only $233 \mathrm{MW}$. Apart from the afore-mentioned countries, there are several other countries in Europe that have the total solar collectors potential higher than the capacity of 2 GW achieved by Poland, including France, Spain, the Netherlands or Turkey. Poland is now approaching the levels reached in the Czech Republic, where the solar collectors market has been stagnating for several years, but where the solar collectors boom observed a decade ago, driven by high feed-in tariffs, has now brought the Czech solar collectors potential to ca. 2.2 GW. In recent months, Poland has overtaken Romania (1.37 GW), Austria (1.27 GW) and Bulgaria $(1.4 \mathrm{GW})$ in terms of the installed solar collectors capacity [8-11].

\subsection{Transformation of the Polish economy towards zero-emissions}

Poland has a lot to catch up with in terms of renewable energy production. The hitherto policy was based on gradual evolution and insufficiently rapid increase in the involvement in solar collectors installations rather than a leap in economic transformation in this respect. The above stems from the relatively high share of energy obtained from minerals (coal and lignite), whose price is relatively lower. What is also significant is the cost of transforming the existing capital and human resources used to produce such energy, which contributes to social tensions. The indicted reasons resulted in a lack of measurable support for the development of solar collectors production and had a significant impact on the development in this respect in comparison with other developed EU countries. In order to catch up in this respect, Poland prepared and introduced at the end of 2019 [12] an amendment to the law, allowing to arouse a greater interest in energy production of prosumers, who may include selected entrepreneurs. In the amendment of the act on Renewable Energy Sources, a number of significant changes were introduced to the support system for electricity generated from solar collectors, such as extension of the definition of a prosumer to companies for which energy production does not constitute the predominant objects and offers them an opportunity to exercise the right to discounts; energy settlement in longer billing periods; no necessity to prepare a construction design for the smallest micro installations of up to $6.5 \mathrm{~kW}$; the possibility of locating micro installations in areas which are not intended for production purposes, entry into force of the so-called thermo-modernisation relief in personal income tax, etc. The relief allows natural persons to deduct from their taxable base the expenses incurred, among others, on solar collectors and accessories, as well as their installation. However, the deduction may not exceed EUR 12,050, and in September 2019 the VAT rate for solar collectors functionally linked to a building of the area of up to $300 \mathrm{~m}^{2}$ was harmonised. All such systems are subject to $8 \%$ VAT [12]. 
As it stems from the projections presented by independent organisations in various countries (such as the OECD [13]), energy demand will grow [13-17] and the global energy consumption will increase by about one third by 2040. Thus, the use of the solar energy for energy production is of crucial importance. Solar energy is the most intense source of energy, which makes $89 \mathrm{PW}$ reach the surface of the Earth, which is ca. 6,000 times more than the total demand (ca. 15 TW) [18]. The conclusion that may be drawn is that solar energy is the energy of the future. Research is currently being conducted in the world on the possibilities of using this energy source. The development of solar collectors technologies is of key importance for the transformation of the economy towards zero emission. The National Energy and Climate Plan for 2021-2030 indicates the essence of the development of this source of energy generation [16]. The development of this source is important for the country's energy security and diversification of energy sources. Many EU countries are accelerating the implementation of solar projects in order to fulfil their renewable energy obligations. In the next two years we will observe a significant increase in the number of installations. More and more frequently, the prices guaranteed by RES tenders are lower than average electricity prices offered on the market. New, subsidy-free business models dedicated to large-scale solar collectors power stations are emerging, alongside tenders, such as energy purchase agreements between producers and major consumers [19]. The above may make Poland one of the largest RES construction sites in Europe. Exploiting the national potential of the solar collectors sector may not only contribute to building new, innovative branches of the economy, but also to strengthening the competitiveness of Polish entrepreneurs on foreign markets.

According to the projections included in the draft of Poland's Energy Policy by 2040, dated 8 September 2020, there will be a significant increase in the installed capacity in the solar collectors, up to the level of ca. 5-7 GW in 2030 and ca. 10-16 GW in 2040 [16]. Taking into account, among other things, the technical specifications of the collectors, the meteorological conditions and the optimal angle inclination towards the Sun, in Poland it is possible to reach annually ca. 9,876 kWh of green electricity from a $10 \mathrm{kWp}$ solar collectors installation. For example, the use of 1 square metre of solar collectors in a detached house reduces emissions of $\mathrm{SO}_{2}, \mathrm{NO}_{x}$ and $\mathrm{CO}_{2}$ by $125 \mathrm{~kg} / \mathrm{year}$ and reduces the demand for conventional energy by $1,250 \mathrm{kWh}$ [20]. Such actions are considered a priority in the energy policy of the European Union countries.

\subsection{Solar collectors installation as the cheapest method of electricity generation}

As regards the known methods of generating electricity that use the energy of solar radiation, solar collectors installation is the cheapest and simplest solution. What is the greatest problem in the Polish energy sector is the sustained, growing cost trend. With energy prices frozen by law in 2019 (at the level of June 2018) and constantly rising costs, it will not be possible to avoid high price increases in 2021 [4]. The further increase in energy costs and prices (within 2-3 years) will have to be shared by all energy consumers, including households, but also industry, farmers, public utilities. In addition, it will entail an increase in food and service prices for people. Furthermore, this thesis is confirmed by the high electricity prices in Poland as compared to other EU countries. As it stems from Eurostat data [3], among Member States of the European Union, electricity prices for households were the highest in the second half of 2019 in the following Member States: Denmark (0.2924 EUR/kWh), Germany (0.2873 EUR/kWh) and Belgium (0.2860 EUR/kWh), while the lowest electricity prices were recorded in: Bulgaria $(0.0958$ $\mathrm{EUR} / \mathrm{kWh}$ ) and Hungary (0.1097 EUR/kWh). Poland, with the average rate of (0.1376 EUR/kWh), is one of the countries in the middle of this list. Figure 2 shows the percentage change in electricity prices for households, including all taxes (including VAT), in national currencies from the second half of 2018 to the second half of 2019. It may be observed that from year to year total prices have fallen in $10 \mathrm{EU}$ Member States, including Poland, where tax reductions are relating to the installation of renewable energy sources. A similar downward trend may be observed in Poland for non-household consumers, which is another argument for investing in the RES and, in particular, solar collectors. 


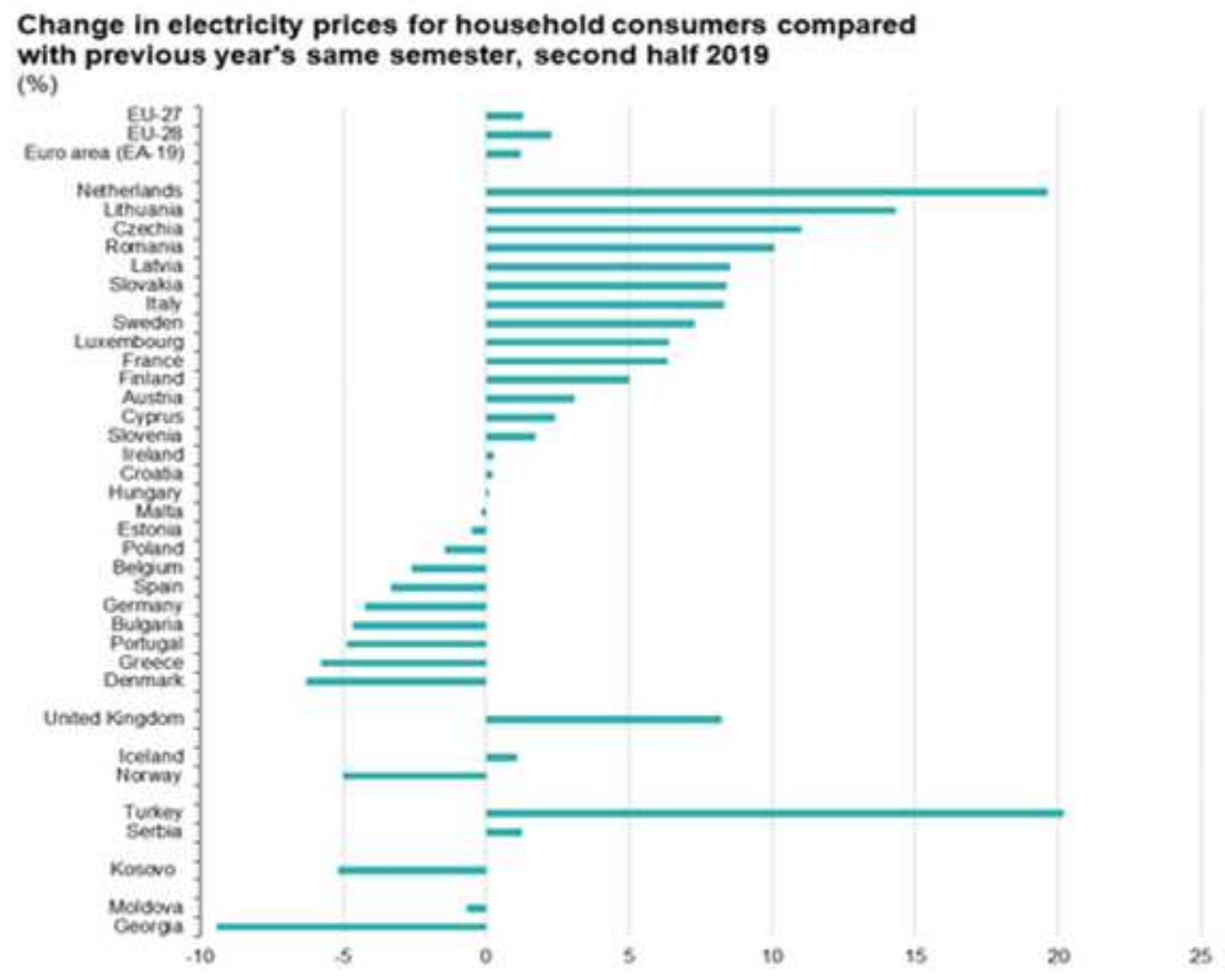

Figure 2. Change in electricity prices for household consumers compared with previous year's same semester, second half of 2019 [3].

Another argument for investing in solar collectors installations in Poland is solar radiation, which is an inexhaustible and widely available energy source. In addition, the Another argument for investing in solar collectors installations in Poland is solar radiation, provides a number of benefits, such as lightweight design, no emissions or noise, no need for constant operation and the ability to operate in different weather conditions. What has to be considered before making a decision on which installations to choose is the cost of their construction, durability and efficiency. These criteria should be the basis for the selection, from a range of models available on the market, offered by global manufacturers, of solar collectors that will provide $70 \%$ of the desired energy on average during the year and $100 \%$ during the summer months. With solar installations, one may completely resign from supplementary heat in summer, while in the remaining months an independent heat source, e.g. a low-temperature oil or gas boiler or condensing boiler, may be used to heat water.

What is more, solar collectors, which generate a significant part of energy in summer, may be the best solution to the problem of the power balance in summer (i.e. providing an appropriate amount of electricity needed in the Polish power system) [1]. Problems with the power balance in summer, resulting in (among other things) the limitations of energy supplies faced by Polish consumers in 2015 and 2016, stem from the specificity of the Polish energy market, which is characterised by the dominant role of hard coal and lignite fired generation sources requiring significant quantities of water for cooling, a dynamic increase in the demand for power in summer, caused by the widespread use of airconditioning and cooling systems, a significant share of heat and power plants in covering the peak load of the system in winter, a very weak connection between the Polish power system and the systems of the neighbouring countries, which limits the possibility of supplementing the deficit in the power balance with imports, etc. The production of electricity from solar collectors may be a natural solution to the outlined gap in electricity production in summer. 


\subsection{Solar collectors market in Poland as compared with other EU countries}

The solar collectors market in Poland has a huge but so far highly untapped development potential. At the end of 2018, the total capacity of the RES installations connected to the power grids, as identified by the Office for Energy Regulation [21], was 8,593 MW, and the solar collectors sources accounted for only $1.7 \%$ of licensed sources (Fig. 3), but after 5 years of incubation in a niche, the solar collectors technology has a chance to become the second (after onshore wind power) RES technology in Poland within a few years.

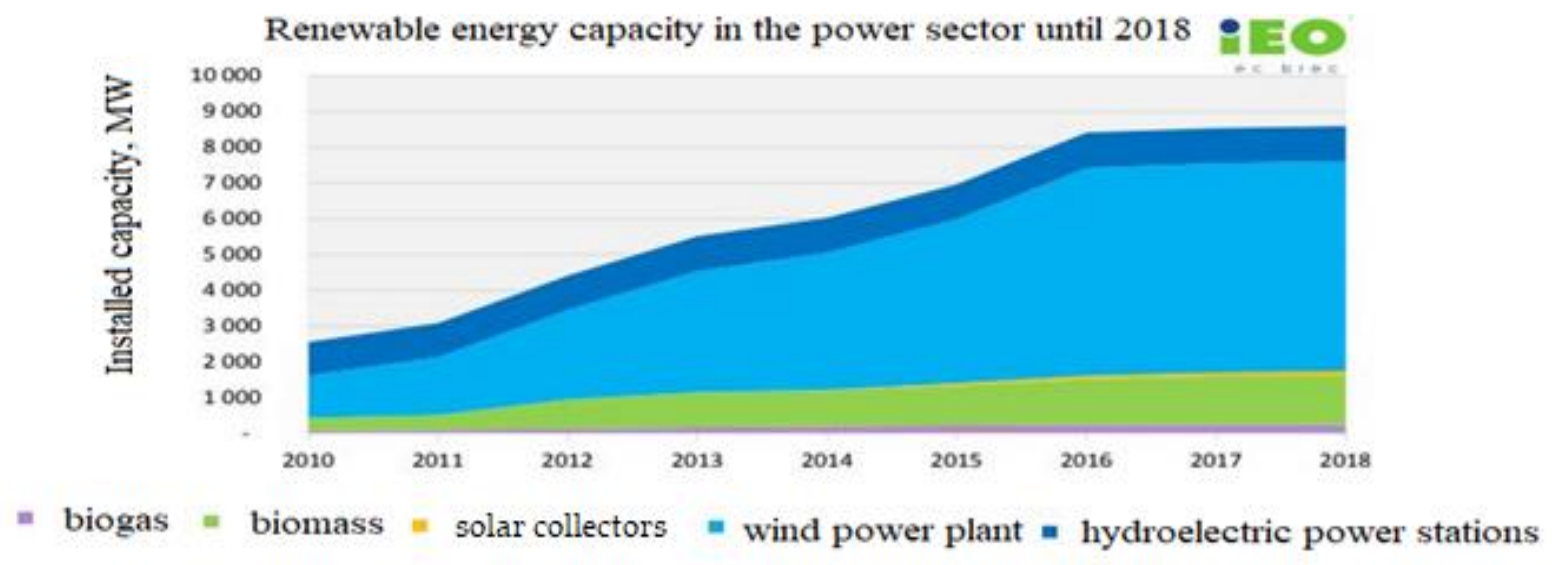

Figure 3. Installed capacity in RES installations for electricity generation. Study of IEO based on the data of the Office for Energy Regulation [21].

Fig. 3 shows only large installations with a license and small RES installations, which gives in total only $147 \mathrm{MW}$ of solar collectors capacity at the end of 2018. The real power of all solar collectors installations in Poland is much higher, it is often not included in official statistics and grows fastest of all technologies in the power industry. According to the Institute of Renewable Energy, the full statistics of the installed capacity in solar collectors sources include:

- solar collectors micro installations, of the capacity of up to $50 \mathrm{~kW}$, whose total capacity was $350 \mathrm{MW}$ at the end of 2018 and may currently exceed even $500 \mathrm{MW}$,

- small solar collectors installations, of the capacity of 50-500 kW, whose total capacity reaches currently 33 MW (as of the end of April 2019),

- solar collectors installations of the capacity exceeding $500 \mathrm{~kW}, 75 \mathrm{MW}$,

- solar collectors installations that have won RES auctions and have already been completed, of the total capacity of ca. $170 \mathrm{MW}$ - most of them are installations of the capacity close to $1 \mathrm{MW}$, but there are also individual installations of the capacity below $500 \mathrm{~kW}$.

Taking into account the afore-mentioned groups of solar collectors installations, the total installed capacity in solar collectors sources may currently reach ca. $700 \mathrm{MW}$.

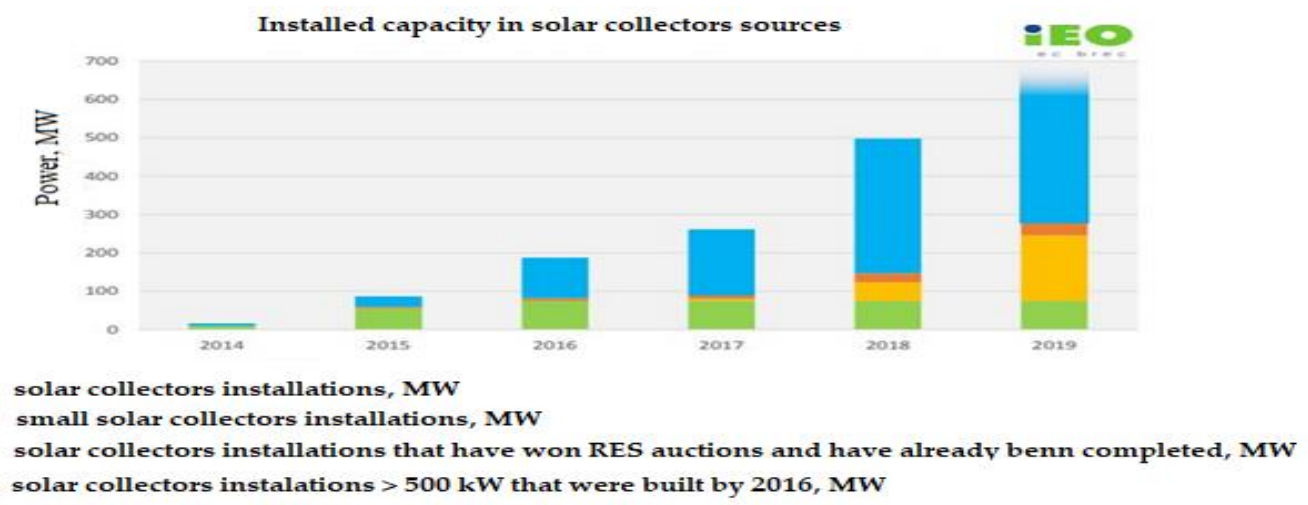

Figure 4. The installed capacities in solar collectors installations in Poland (as of April 2019) [21]. 
Figure 4 shows the cumulative installed capacity in solar collectors, connected to the grid in individual years, for Poland, by type of installation. The dynamic development of solar collectors has been observed for 5 years, but particularly spectacular growth took place in 2018 and reached over $90 \%$. The solar collectors sector grew in all market segments and power ranges, including micro installations (up to $50 \mathrm{~kW}$ ), small installations (up to $500 \mathrm{~kW}$ ) and solar collectors farms (up to 1,000 kW). In 2019, the capacity of $640 \mathrm{MW}$ was installed in micro installations, which means an almost threefold increase yearover-year; already in Q1 2020, solar collectors micro installations of the capacity of ca. 300 MW were connected to the grid. The large increase in the capacity of micro installations in the first quarter of this year means that despite the beginning of the pandemic (and the first symptoms of the economic slowdown), prosumers are still interested in investing in solar collectors and the global pandemic limits the development of this sector to a relatively small extent. At the end of 2019, micro installations accounted for over $70 \%$ of the total installed capacity in solar collectors. In 2025, the total installed capacity in solar collectors may reach $7.8 \mathrm{GW}$, which means that already in 2025 the capacity of solar collectors sources will exceed the capacity assumed in the National Energy and Climate Plan for 2030 [10]. The observed and projected market growth is particularly high in the sector of prosumers and farm developers and creates a market for installation companies and Polish manufacturers and suppliers of the equipment, whose development provides new jobs and generates value added.

Solar collectors will contribute to the breakthrough that begins the energy transformation in Poland. It is not only the main area of investment in renewable energy, but also in the entire Polish power industry. The RES industry was the only industry that was able to mobilise more capital for investment between 2019 and 2020 than the entire conventional energy sector. This industry is also able to win the confidence of Polish and foreign capital investors, which is confirmed by the stock exchange index IEO [22], presented in Figure 5.

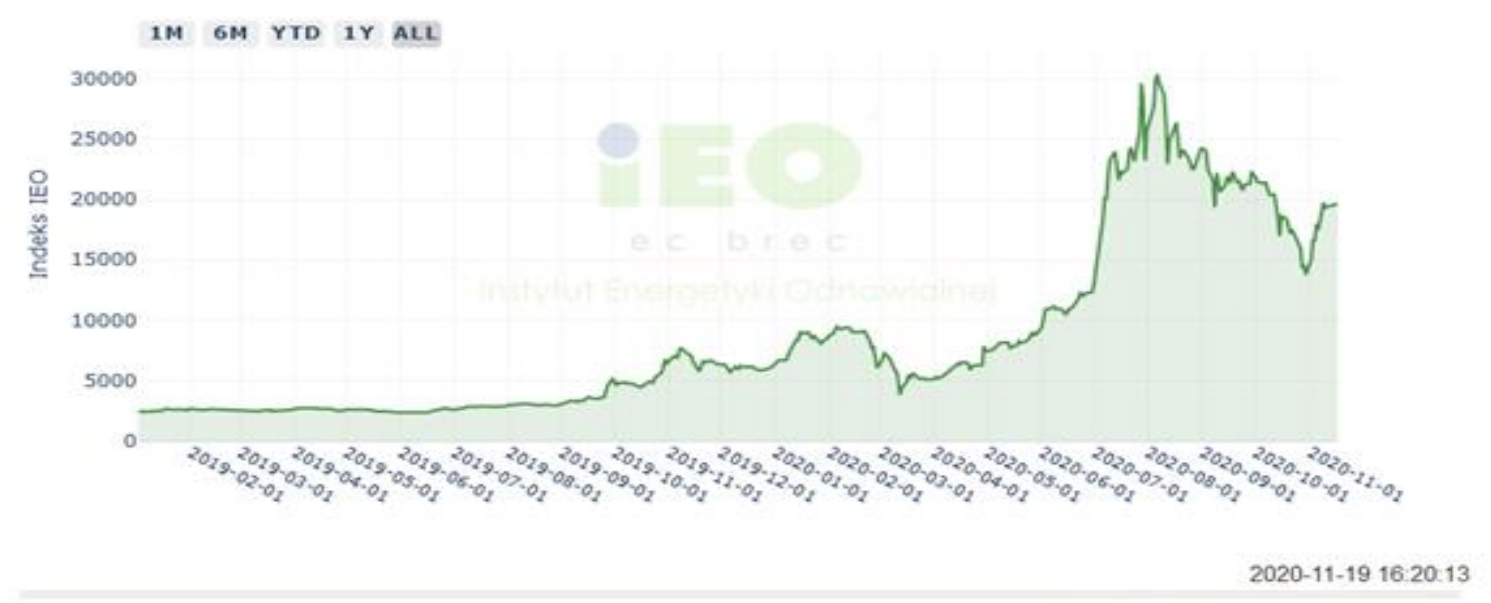

Figure 5. The indicator of the economic situation of the solar collectors market in Poland [22].

As a result of analysing the extremely dynamic solar collectors market, the Institute of Renewable Energy developed the first, copyright stock exchange indicator called IEO. The indicator includes the listings of solar collectors companies operating on NewConnect and on the main floor of the Warsaw Stock Exchange. It is a simple and transparent indicator of the economic situation of the solar collectors market in Poland.

\section{Meteorological possibilities of using solar collectors installations in Poland}

What is an important assumption determining the profitability of investing in the solar collectors is, apart from lower electricity bills, a favourable level of insolation over the Polish territory. Each region of Poland has different conditions, such as cloudiness, lie of the land, latitude and longitude. Since Poland is a country with a relatively small latitudinal and longitudinal range, the differences in insolation are not great. Meteorological conditions have a significant impact on the efficiency of solar 
collectors and are connected with the most important parameters determining the potential of solar energy use, such as solar intensity $\left(\mathrm{W} / \mathrm{m}^{2}\right)$, total solar radiation $\left(\mathrm{J} / \mathrm{m}^{2}\right)$ and insolation. These parameters define both total radiation and its components, i.e. direct and diffuse radiation. In Poland's latitudes, the sum of direct and diffuse radiation reaching the earth's surface may have the maximum instantaneous value of $1 \mathrm{~kW} / \mathrm{m}^{2}$. The greatest amount of solar energy in Poland reaches the collector surface in June when the sky is cloudless, when the sun is at its highest point above the horizon $\left(62.4^{\circ}\right)$. In December, on the other hand, this energy is much lower because the Sun is at the lowest point (15.5\%) [23]. Summer months are characterised by the greatest number of hours of insolation, direct radiation may constitute $90 \%$ of the total radiation reaching the earth and thus reach $1,050 \mathrm{~W} / \mathrm{m}^{2}$. During the same period, but when the sky is completely clouded, only diffuse radiation reaches the earth's surface and its value varies between 50 and $150 \mathrm{~W} / \mathrm{m}^{2}$. In the period from October to March, the number of hours of insolation is the smallest and, in addition, the reception of this small amount of energy is reduced by stronger winds and lower air temperatures. Figure 6 presents a map of average insolation in particular regions of Poland. It is assumed that the greatest amount of insolation in Poland occurs in the southeastern part of the country and reaches ca. 1,624 h/year.

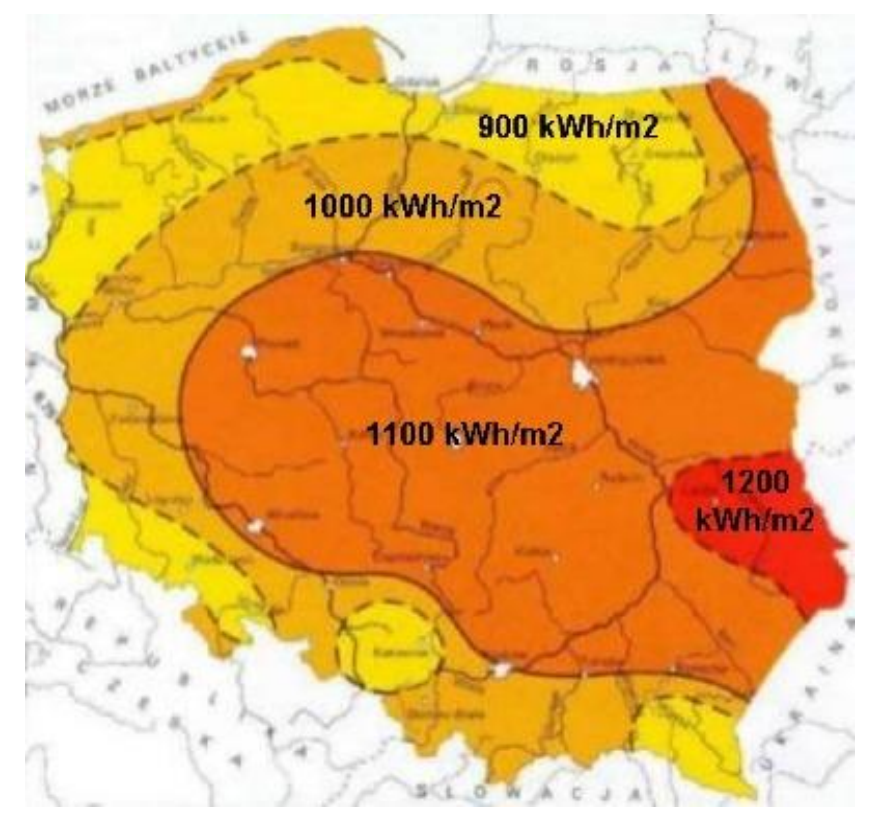

Figure 6. Map of average insolation values [24].

Poland is located between $49^{\circ}$ and $54.5^{\circ}$ north latitude in a temperate climate zone. The daytime, i.e. the time from sunrise to sunset, covers over $51 \%$ of 8,767 hours per year. This period is 24 hours longer in the northern ends of the country than in the southern ends of Poland. In winter the situation is different, the daytime in the southern part of Poland lasts almost one hour longer than in the northern part. In the summer, the opposite is the case. In June in the northern ends of Poland, the daytime hours are $71.5 \%$ of the hours in the month, in the centre - $69 \%$ and in the south - $67 \%$. In December, there are only $29.5 \%$ daytime hours in the north, $31.7 \%$ in the centre and $34.7 \%$ in the south. A conclusion that may be drawn on the basis of the results of the research on Poland's insolation is that it is profitable to install a solar collectors in practically every place in Poland, but there are regions where the sun "shines more". The above-average profits from the installation may be achieved by the inhabitants of the south-eastern part of Poland [23].

It is noteworthy that if the solar collector surface may not be oriented to the south, then a flat position of the collector should be used. The above does not affect the fact that with a $30^{\circ}$ inclination of the collector with the orientation of $45^{\circ}$ east or west from the south, the yield level is $95 \%$ of the optimum yield. If the collector is directed to the east or west, the yield is up to $85 \%$, provided that the inclination of the collector is between $25^{\circ}$ and $40^{\circ}$. A steep collector position is the best design solution, which allows to obtain the same amounts of energy throughout the year and avoid inclination angle below $20^{\circ}$ in 
order to protect the collector from contamination. However, as it stems from the latest research, it is possible to increase the sum of solar radiation per inclined surfaces (as specified in Table 1) in relation to horizontal surfaces by $30 \%$.

Table 1. Optimal angle of inclination of the solar collector in different periods of its use in Poland [25].

\begin{tabular}{|c|c|c|c|c|c|c|c|c|c|c|c|c|}
\hline Months & Jan & Feb & Mar & Apr & May & Jun & Jul & Aug & Sep & Oct & Nov & Dec \\
\hline $\begin{array}{c}\text { Optimum } \\
\text { angle, },\end{array}$ & 60 & 55 & 45 & 30 & 15 & 10 & 15 & 30 & 45 & 55 & 65 & 65 \\
\hline
\end{tabular}

Figure 7 presents daily radiation power in Poland in the most favourable period and the least favourable period during the year.
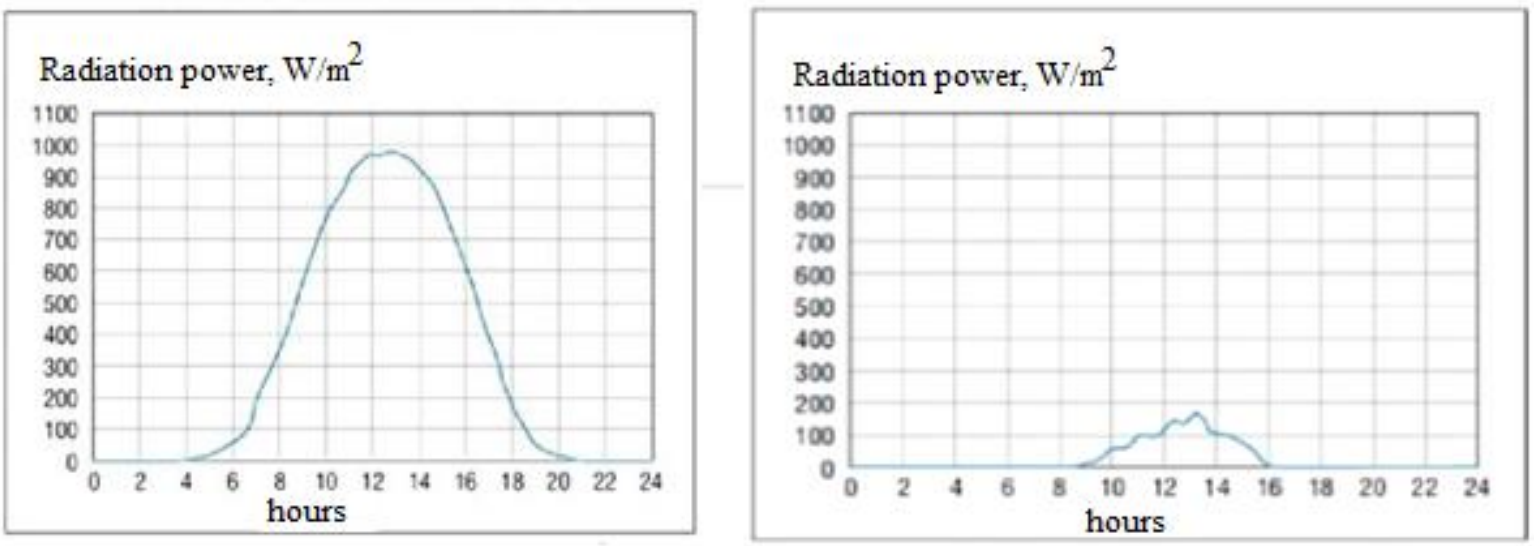

Figure 7. Daily radiation power in Poland: a) on a cloudless day in June, b) on a cloudy day in December [18].

Figure 8 shows a schematic representation of the change in efficiency of the solar collectors depending on the intensity of solar radiation.

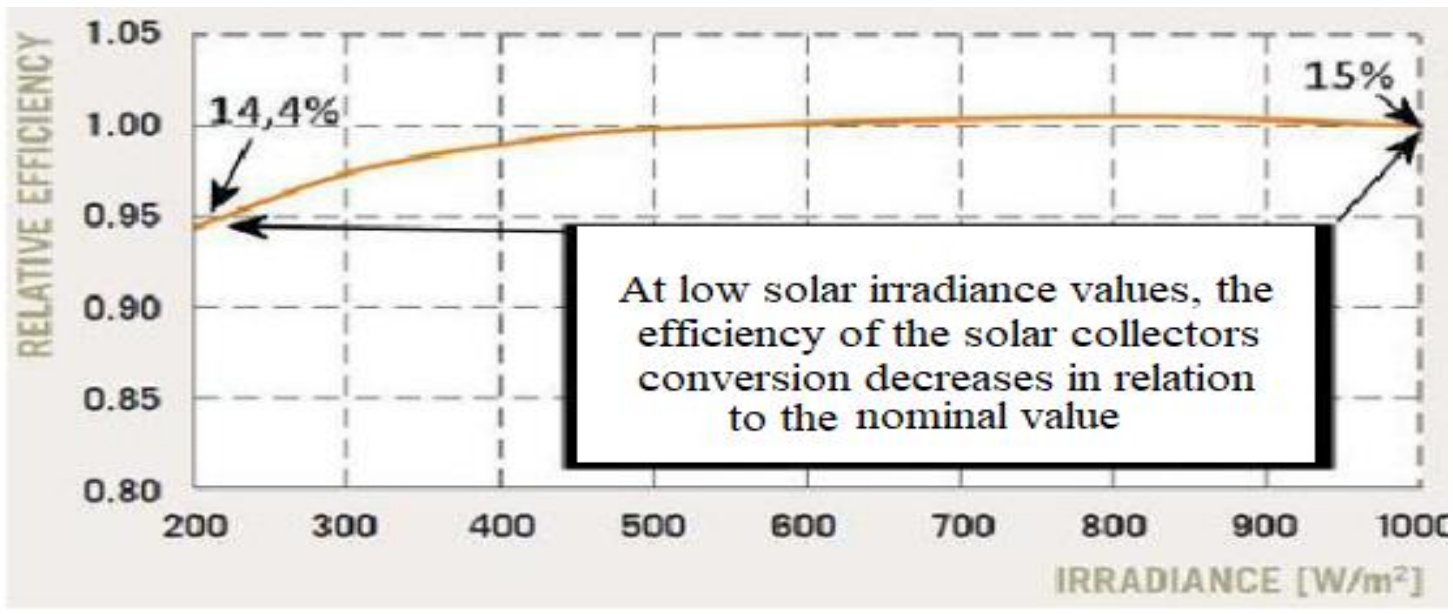

Figure 8. Change in efficiency of the solar collectors depending on the intensity of solar radiation [26].

Climatic conditions in Poland have the greatest impact on the profitability of solar collectors and the possibility of using solar radiation energy. A significant part of the potential for solar technology may be found in small roof installations. Assuming that a good-class solar collector may provide from 1 square metre ca. $500 \mathrm{kWh}, 1.8 \mathrm{GJ}$ of thermal energy may be obtained per year. For this purpose, it should be assumed that in order to achieve the above condition, the area of the collectors should be ca. $740 \mathrm{~km}^{2}$. Until long-term energy storage technologies are developed, their use will be the most effective in particular in spring and winter. 


\section{Materials and Methods}

The purpose of the research was to determine the profitability of using a solar collectors producing electricity in a single-family residential building for one calendar year, with local weather conditions, as exemplified by Cracow in Poland. On the basis of the collected data and the adopted assumptions, calculations were made to estimate the amount of energy that may be obtained in the form of heat. A single-family house of the area of $150 \mathrm{~m}^{2}$ was subject to economic analysis. The demand for thermal energy is $16,000 \mathrm{kWh}$, including 6,000 $\mathrm{kWh}$ for hot water preparation and 10,000 kWh for heating. Hot water temperature: $\mathrm{t}_{\mathrm{w}}=50{ }^{\circ} \mathrm{C}$, cold water temperature $\mathrm{t}_{\mathrm{z}}=7{ }^{\circ} \mathrm{C}$. Radiation conditions, reaching 1,000 $\mathrm{kWh} / \mathrm{m}^{2}$ per year with the average annual insolation of 1,600 hours, are favourable. In addition, the solar collectors will be installed on the roof, positioned to the south and the angle of inclination to the surface will be $45^{\circ}$. The calculations will be made for a vacuum collector of the actual absorption area $\mathrm{A} \approx 6.5$ $\mathrm{m}^{2}$, efficiency $\eta=0.8$ and daily output of $300 \mathrm{dm}^{3}$. The number of vacuum tubes is 40 , the tube lengths are $1,800 \mathrm{~mm}$ and the diameter is $58 \mathrm{~mm}$. The height of the collector is $2,000 \mathrm{~mm}$ and its weight is $93 \mathrm{~kg}$, $\mathrm{P}_{\mathrm{o}}=4.5 \mathrm{~kW}$.

On the basis of the collected data and the adopted assumptions, calculations were made to estimate the amount of energy that may be obtained in the form of heat, depending on the absorber area. The amount of heat, adjusted appropriately taking into account the existing demand for heat, allows to determine the NPV, assuming the price of energy from the replaced heat source. Next, the internal rate of return (IRR) was calculated. The data used for the calculation are derived from measurements made on an actual solar installation, which allows to compare the results with other installations. The obtained heat yield $U_{s t j} j$ was referred to the radiation for an average year. In addition, the calculations were made with the use of the radiation model according to the following formula:

$$
U_{s t j}=\frac{\sum y\left(U_{n j y} \cdot \frac{I_{p t j}}{I_{n j y}}\right)}{3}
$$

where:

$U_{n y j n}$ - measured solar yield in month $j$, year $\mathrm{y}, \mathrm{kWh} / \mathrm{month}$,

Iptj - insolation on a flat surface by average year in month $j, \mathrm{kWh} /($ square metre $\mathrm{x}$ month),

Injy - measured solar radiation of the flat surface in month $j$, year $y, \mathrm{kWh} /($ square metre $\mathrm{x}$ month),

$\mathrm{y}$ - measurement years.

Since the insolation of Ijrw is a stochastic variable, in the further calculations the insolation was assumed on the basis of the value drawn with the use of the Monte Carlo method. The model of statistical deviations of solar yields used in the simulation describes relationship (2). The simulation allowed to adjust the average solar yields to the average insolation and its standard deviation over the years, taking into account the amount of the heat demand.

where:

$$
I_{j r w}(\beta, \gamma)=f\left(s d\left(I_{p t j}\right), I_{p t j}\right)
$$

Ipt $j$ - insolation of a flat surface in month $\mathrm{j}$ of a typical meteorological year, $\mathrm{kWh} /\left(\mathrm{m}^{2} \mathrm{x}\right.$ months $)$, $\operatorname{sd}(I p t j)$ - standard deviation of the insolation from that in a typical meteorological year in month $j$, $\mathrm{kWh} /\left(\mathrm{m}^{2} \times\right.$ months $)$.

In order to improve the economic effect, it was proposed to increase the area of the absorbers. Furthermore, on the basis of actual measurements from this installation, reflecting the influence of many non-measurable factors on the efficiency of solar energy conversion, simulations of the economic effect were made for different heat demand volumes. The obtained results have been generalised, which allows to use them in the process of selecting the size of collector area for similar installations. 


\section{Results and Discussion}

The investment outlays relating to the extension of the system for the preparation of hot water with a solar system for the analysed building were made in accordance with the methodology presented below.

The energy produced by a solar collector during the year is calculated with the use of the following formula:

where:

$$
\mathbf{Q}_{\mathbf{k}}=\mathbf{G} \cdot \mathbf{A} \cdot \boldsymbol{\eta}
$$

$\mathrm{G}$ - annual radiation,

A - absorber surface,

$\eta$ - collector efficiency.

$$
Q_{\mathrm{k}}=1000 \mathrm{kWh} / \mathrm{m}^{2} \cdot 6,5 \mathrm{~m}^{2} \cdot 0,8=5200 \mathrm{kWh}
$$

The heat loss in the supply lines and exchanger is ca. $10 \%$, or $520 \mathrm{kWh}$. The amount of electricity supply required for the system (pump, controller) is ca. $100 \mathrm{kWh}$. The net energy of the system is as follows:

$$
Q_{u}=5200 \mathrm{kWh}-620 \mathrm{kWh}=4580 \mathrm{kWh}
$$

In order to heat $300 \mathrm{dm}^{3}$ of water to $50^{\circ} \mathrm{C}$, there must be supplied the heat energy of the following value:

$$
\mathrm{Q}_{\mathrm{w}}=\mathrm{m} \cdot \mathrm{C}_{\mathrm{p}} \cdot \Delta \mathrm{T}=300 \cdot 0,0011 \cdot(50-7)=14,19 \mathrm{kWh}
$$

Assuming the heat loss of $15 \%$ in the system, the amount of thermal energy to be supplied to the system during the day is obtained as follows:

$$
Q_{c}=14,19 \mathrm{kWh}+15 \%=16,32 \mathrm{kWh}
$$

i.e. the annual energy consumption will be:

$$
Q_{r}=16,32 \cdot 365=5956 \mathrm{kWh}
$$

For the collector to be able to heat $300 \mathrm{dm}^{3}$ of water to $50^{\circ} \mathrm{C}$ on average per year, it has to work over the following time:

$$
Q_{c}=P_{o} \cdot t \rightarrow t=\frac{Q_{c}}{P_{o}}=\frac{16,32}{4,5} \approx 3,6 \mathrm{~h} / \text { dobę }
$$

Assuming that the amount of energy in the daytime during the whole year changes within the range of $0-5 \mathrm{kWh} / \mathrm{m}^{2}$, at full insolation the power of the collector will be as follows:

$$
P_{\mathrm{k}}=5 \mathrm{~kW} / \mathrm{m}^{2} \cdot 6,5 \mathrm{~m}^{2}=32,5 \mathrm{~kW}
$$

and the time required to heat up $300 \mathrm{dm}^{3}$ will be as follows:

$$
\mathrm{t}=\frac{\mathrm{Q}_{\mathrm{c}}}{\mathrm{P}_{\mathrm{k}}}=\frac{16,32}{32,5} \approx 0,5 \mathrm{~h}
$$

In this case the efficiency of the system will be as follows:

$$
\eta=\frac{Q_{u}}{Q_{r}}=\frac{4580}{5956} \approx 0,77
$$

The calculation shows that the average annual savings that may be achieved when heating water with the use of solar panels amount to EUR 550:

$$
4580 \mathrm{kWh} \cdot 0,12 € / \mathrm{kWh} \approx 550 € / \text { year }
$$


The main factor influencing the degree of profitability of the solar collectors application is its purchase price - the lower the price, the quicker rate of return (with similar equipment efficiency) [27]. On the domestic market there are representatives of many companies specialising in solar collectors. These systems differ in quality, technical specification, price and efficiency [28]. The system selected for this particular analysis is a system with two flat-plate collector panels of the collector area of $6.5 \mathrm{~m}^{2}$ and the final price of 4,500 EUR. The costs connected with the operation of the system are assumed to reach EUR 50. Taking into account the investment and operating costs as well as profit for different conventional energy carriers, the payback time presented in Table 2 was obtained.

Table 2. Profit obtained from saving of different conventional energy carriers for one year and the payback time in the event of the replacement of different conventional energy carriers.

\begin{tabular}{|l|c|c|}
\hline \multicolumn{1}{|c|}{ Energy carrier } & $\begin{array}{c}\text { Profit, } \\
\text { EUR }\end{array}$ & Payback time, years \\
\hline Hard coal & 200 & 30 \\
\hline Network heat & 170 & 20 \\
\hline Natural gas GZ 50 & 280 & 18 \\
\hline Fuel oil & 360 & 13 \\
\hline Liquefied petroleum gas (LPG) & 550 & 10 \\
\hline Electricity (fixed tariff) & 490 & 8 \\
\hline
\end{tabular}

Source: own study.

Summing up, the investment involving the use of solar collectors to generate electricity for singlefamily buildings, where water is heated by electricity or gas, will pay back after 8-9 years. Taking into account the average life of solar collectors, i.e. 20-25 years, the investment is profitable, since it will yield a measurable return in the tenth to eleventh year of operation. Revenues from the investment under analysis will be revenues from the sale of energy to the grid, calculated in accordance with the guaranteed fixed tariff and then in accordance with the assumed purchase price of energy on the competitive market, subject to annual adjustment with the assumed energy price inflation index) and savings from reduced energy consumption from the grid (calculated in accordance with the price at which the house owner buys energy from the grid operator). In the analysed case, the dominant source of revenues from the 16th year of operation will be revenues from sale of energy, as shown in Figure 9. These calculations do not take into account a possible increase in energy prices, a decrease in the efficiency of the solar collectors or the cost of the loan, usually used for financing such investments.

EUR

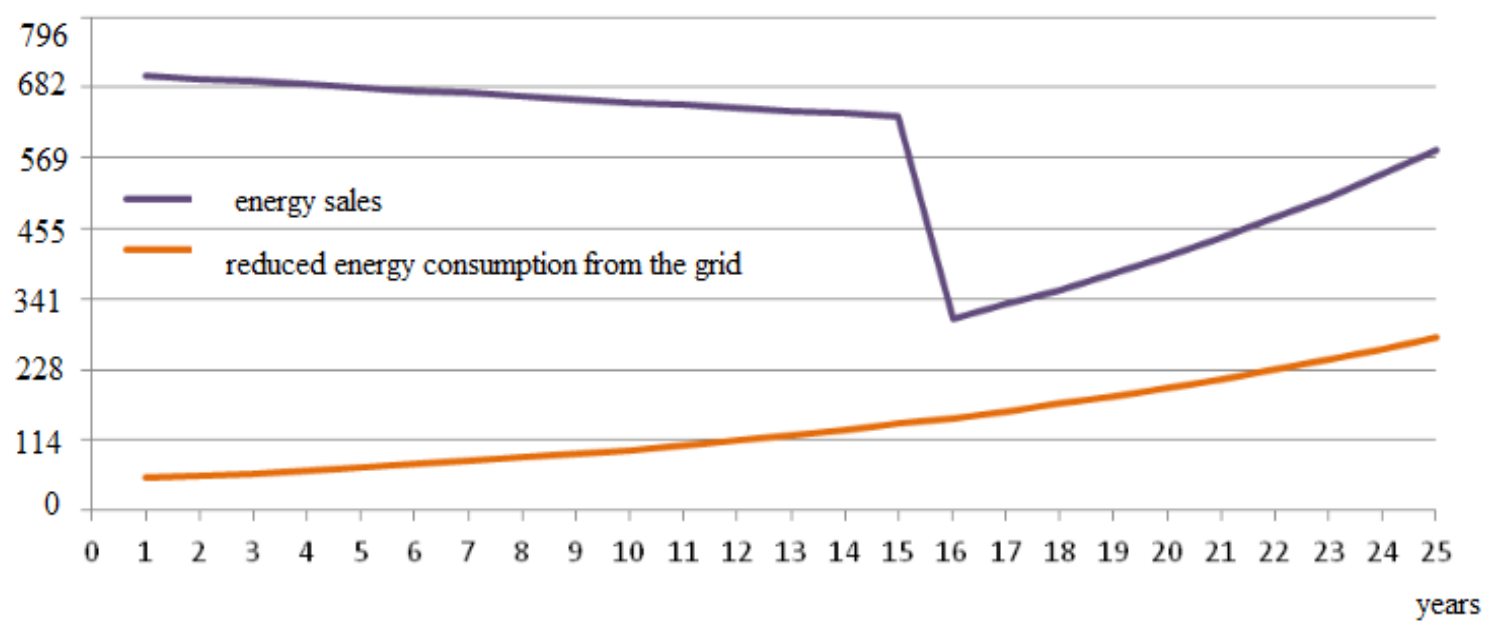

Figure 9. Revenues from the sale of energy generated in the solar collectors system and from reduced consumption of energy from the grid.

Source: own study. 
What also affects the investment profitability is the area of the absorber used for calculations [29]. On the basis of the collected data and the adopted assumptions, calculations were made to estimate the amount of energy that may be obtained in the form of heat, depending on the absorber area. The amount of heat, adjusted appropriately taking into account the existing demand for heat, allows to determine the NPV, assuming the price of energy from the replaced heat source. Next, the internal rate of return (IRR) was calculated. Figure 10 shows that the annual solar yields increase proportionally to the area of the absorber. Within the range of $2-5 \mathrm{~m}^{2}$ they reach $800 \mathrm{kWh}$ and $1,800 \mathrm{kWh}$, respectively, for the extreme values. In contrast, they differ by $600 \mathrm{kWh}$ between 6 and $12 \mathrm{~m}^{2}$.

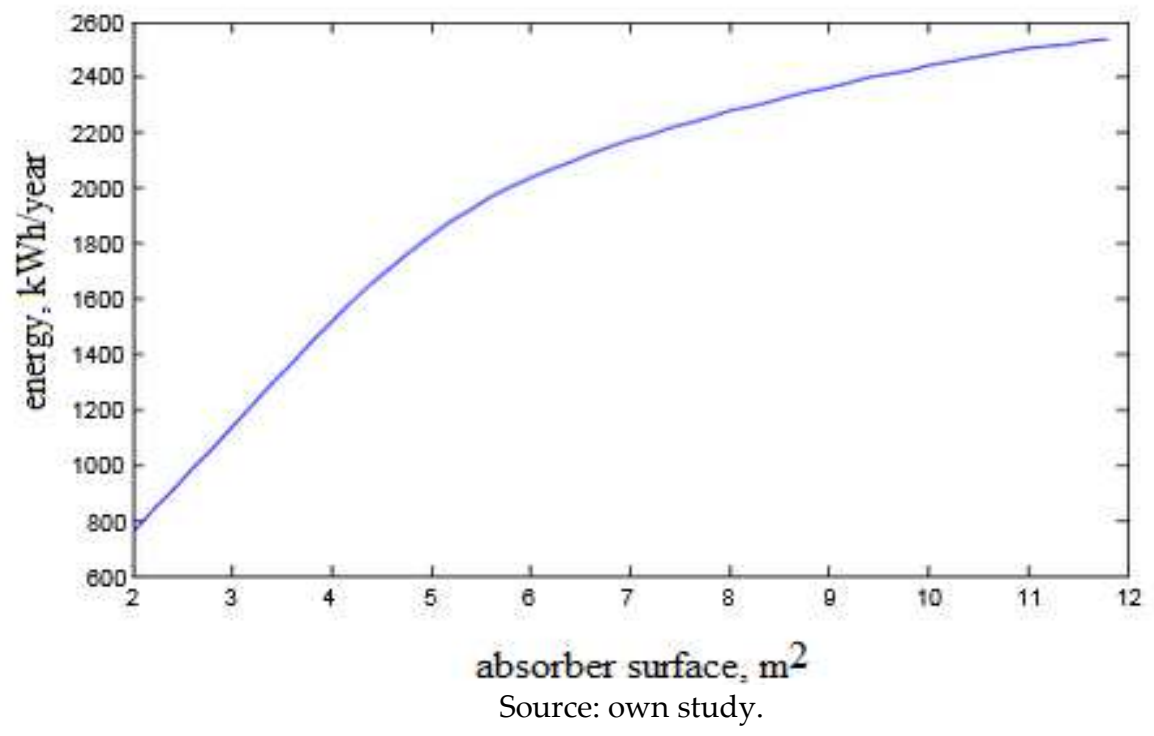

Figure 10. Dependence of annual corrected solar yields for the analysed system as a function of the absorber area.

On the basis of the obtained results concerning heat yields, the applicable heat price and fixed and variable costs, NPVs may be calculated as a function of the absorber area, in accordance with the following formula and the internal rate of return (IRR) [30,31]:

$$
N P V=\sum_{i=1}^{n} \frac{N C F_{i}}{(1+k)^{n}}=\sum_{i=1}^{n} \frac{P_{i}}{(1+k)^{n}}-\sum_{i=1}^{n} \frac{N_{i}}{(1+k)^{n}}
$$

where:

$\mathrm{CF}_{\mathrm{i}}$ - net cash flow expected in year $\mathrm{i}(\mathrm{i}=1,2, \ldots, \mathrm{n})$,

$\mathrm{N}$ - initial investment outlay,

$\mathrm{k}$ - appropriate market capitalisation rate,

$\mathrm{n}$ - the lifetime of the project effect in years,

NCFi - net cash flows

$\mathrm{P}_{\mathrm{i}}$ - revenue of the year,

$\mathrm{N}_{\mathrm{i}}$ - expenditure of the year.

$$
I R R=i_{1}+\frac{P V *\left(i_{2}-i_{1}\right)}{P V+|N V|}
$$

where:

IRR - internal rate of return,

$i_{1}$ - interest rate, where NPV $>0$,

$i_{2}$ - interest rate, where NPV $<0$,

PV - NPV calculated in accordance with $i_{1}$,

NV - NPV calculated in accordance with $i_{2}$. 
For the analysed installation, the investment in the extension of the collector area in accordance with the NPV is economically effective for the absorber area within the range of 5.6-7.6 $\mathrm{m}^{2}$, and reaches the maximum value for the absorber area of $6.6 \mathrm{~m}^{2}$, while the absorber area of more than $7 \mathrm{~m}^{2}$ contributes to reducing the value of economic profitability measures. For example, assuming that the heat demand for preparation of $\mathrm{Q}$ of hot water is $6,000 \mathrm{kWh} /$ year in a single-family house and the area of the absorbers is $4 \mathrm{~m}^{2}$, then the NPV is negative (- 533 EUR). Changing the area of absorbers into $6 \mathrm{~m}^{2}$ will result in changing the NPV by EUR 778 as compared with the current NPV (and will amount to EUR 245). Furthermore, on the basis of map charts that may be drawn up for any place in Poland, the user may select the most economically effective area of the collector absorber, taking into account the user's heat demand for hot water preparation. Figure 11 shows a map of the effective solar yields as a function of the absorber surface.

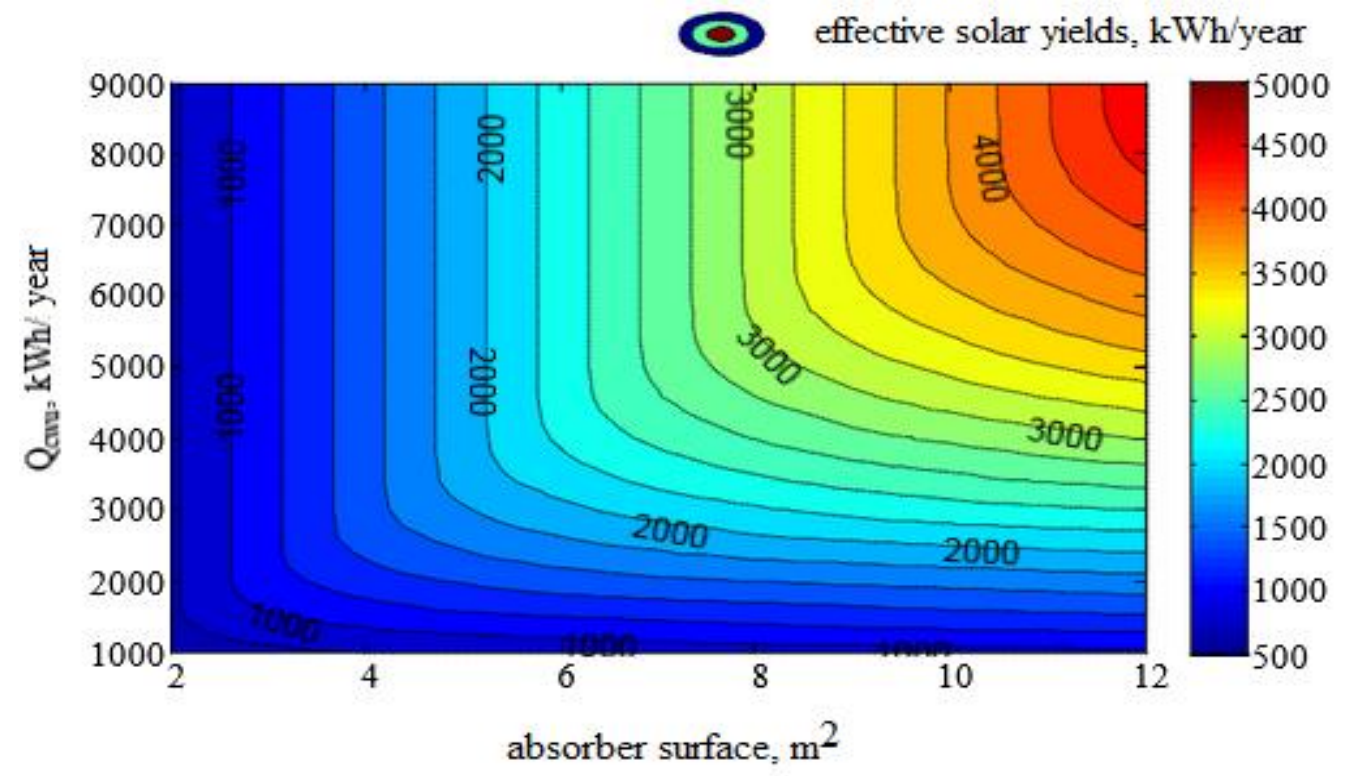

Figure 11. Diagram of examples of effective solar yields as a function of the absorber area and heat demand for hot water preparation.

Source: own study.

Extending the water heating system with a solar system is economically justified (in the event of similar technological solutions) if the annual heat demand is greater than 3,000 $\mathrm{kWh}$. The minimum area of the absorber for a family of five should not reach less than $5 \mathrm{~m}^{2}$. What significantly impacts the economic efficiency is investment costs, which may vary considerably depending on the level of cofinancing (not taken into account in the analysis due to significant differences in legal conditions regarding the level of co-financing), as well as the costs of heat generation in the heat source used so far. Furthermore, the amendment of the RES Act of 2019 assumes that

- the prosumer may use the power grid as an energy storage, provided that he/she has signed a comprehensive contract for the provision of electricity distribution and sale services;

- in the event of installations of the capacity of up to $10 \mathrm{kWp}$, the prosumer may take $0.8 \mathrm{kWh}$ for each $1 \mathrm{kWh}$ of energy introduced to the grid and in the event of installations of the capacity of up to $50 \mathrm{kWp}-0.7 \mathrm{kWh}$ for each $1 \mathrm{kWh}$ of energy introduced to the grid;

- the prosumer does not pay any additional fees to the energy seller for the settlement of the energy input and output - for energy taken from the grid (previously introduced to it), he/she only pays fixed fees relating to energy distribution;

- in the event of solar collectors micro installations, the related formalities come down to reporting this fact to the local electricity provider and signing an amendment to the agreement with the energy distributor;

- non-cash settlement of the amount of energy within the discount system takes place on an annual basis. 


\section{Summing up and conclusions}

When planning an investment in solar collectors, the user is mainly interested in both its energy efficiency and economic viability. Investments in renewable energy sources (including solar collectors) are not low-budget investments in Poland, but the available non-refundable subsidies and favourable financing for the purchase and installation of solar collectors may make them gain in popularity in Poland. The main reason is the cost-effectiveness of purchasing and using green systems for power generation. The cost-effectiveness analysis carried out in respect of a detached house allowed to demonstrate that this project is fully justified. Furthermore, pursuant to the Renewable Energy Sources Act in force in Poland, treating a small entrepreneur as a prosumer who may generally take advantage of favourable conditions for discounting the produced energy leads to very favourable possibilities of settling electricity. Considering an entrepreneur as a prosumer who may use one-off depreciation of a solar collectors installation as a fixed asset and request for VAT refund is what makes such an investment very attractive in financial terms and makes it difficult to find a safe investment alternative characterised by such a high rate of return.

The conducted analyses also lead to several important conclusions concerning the use of this type of systems in single-family houses:

1. The power of the solar collectors should be chosen so that the electricity produced fully balances the energy taken from the grid.

2. The more energy is consumed at the time of its generation, the less energy is introduced to the grid for free.

3. Taking into account the fact that the greatest benefit of a solar collectors may be obtained with consumption of the greatest amount of energy at the time of its generation (balanced energy), it seems that households should also consider changing their routines, so that certain activities, such as washing, cooking, ironing, water heating, are done when the solar collectors generates energy.

It has been shown that the working installation will bring measurable economic benefits in the form of the reduced amount of energy purchased from the current supplier and environmental benefits in the form of reduced emission of carbon dioxide to the atmosphere at the electricity generator. Therefore, the use of solar collectors is an opportunity to reduce the operating costs of small households.

\section{References}

1. Derski, B. Energetyka w Polsce w 2019 roku - moc i produkcja energii wg danych PSE. Available online: https://wysokienapiecie.pl/27524-energetyka-w-polsce-w-2019-roku-moc-produkcja-energii-wg-danych-pse/ (accessed on 13 November 2020).

2. Directive 2009/28/EC of the European Parliament and of the Council of 23 April 2009 on the promotion of the use of energy from renewable sources and amending and subsequently repealing Directives 2001/77/EC and 2003/30/EC (Text with EEA relevance). Available online: https://eur-lex.europa.eu/legalcontent/PL/TXT/?uri=celex\%3A32009L0028 (accessed on 15 November 2020).

3. Eurostat Statistics Explained, Electricity price statistics. Available online: https://ec.europa.eu/eurostat/statisticsexplained/index.php/Electricity_price_statistics (accessed on 13 November 2020).

4. Janoś, K., Polski prąd najdroższy w UE już 7 m-c z rzędu. Tak drogo może być 15 lat. Available online: https://www.money.pl/gospodarka/polski-prad-najdrozszy-w-ue-juz-7-miesiecy-z-rzedu-tak-drogo-mozebyc-15-lat-6576934583294752a.html (accessed on 10 November).

5. Olczak P., Matuszewska D., Kryzia D., Mój Prad" as an example of the photovoltaic one off grant program in Poland, Energy policy journal, 2020, Vol. 23, pp. 123-138 DOI: 10.33223/epj/122482. Available online: https://epj.min-pan.krakow.pl/-Moj-Prad-as-an-example-of-the-photovoltaic-one-off-grant-program-inPoland,122482,0,2.html (accessed on 13 November 2020).

6. Benalcazar, P., Suski, A. and Kamiński, J. The Effects of Capital and Energy Subsidies on the Optimal Design of Microgrid Systems. Energies 2020, Vol. 13, No. 4, DOI: 10.3390/en13040955. 
7. Newseria BIZNES. Polska na piatym miejscu w UE pod względem rozwoju fotowoltaiki. Ten rok może być rekordowy dla branży. Available online:

http://europejskafirma.pl/24168,polska-na-piatym-miejscu-w-ue-pod-wzgledem-rozwoju-fotowoltaiki-tenrok-moze-byc-rekordowy-dla-branzy/ (accessed on 17 November 2020).

8. SolarPower Europe - Leading the Energy Transition. Available online: https://www.solarpowereurope.org/events2/solarpower-summit-2/ (accessed on 14 November 2020).

9. IEO Instytut Energetyki Odnawialnej. Główny raport Solar „Rynek fotowoltaiki w Polsce” 2019. Available online: https://ieo.pl/pl/projekty/raport-rynek-fotowoltaiki-w-polsce-2019 (accessed on 17 November 2020).

10. CIRE.PL Centrum Informacji o Rynku Energii. Report „Rynek Fotowoltaiki w Polsce 2020” Available online: https://www.cire.pl/item,200053,2,0,0,0,0,0,rynek-fotowoltaiki-w-polsce-2020-streszczenie-i-wnioskiraportu.html (accessed on 17 November 2020).

11. IEA. World Energy Outlook 2019-Analysis-IEA; Part of World Energy Outlook IEA: Paris, France, 2019; ISBN 978-92-64-97300-8.

12. The Sejm of the Republic of Poland. Act of 19 July 2019 amending the Renewable Energy Sources Act and Certain Other Acts. Dz.U. 2019 item 1524, Warsaw, Poland, 2019. Available online:

http://isap.sejm.gov.pl/isap.nsf/download.xsp/WDU20190001524/T/D20191524L.pdf $\quad$ (accessed on 14 November 2020).

13 Organisation for Economic Cooperation and Development - OECD Better Policies for better lives. Available online: https://www.oecd-ilibrary.org/social-issues-migration-health/international-migration-outlook2020_ec98f531-en (accessed on 15 November 2020).

14. Ministry of State Assets. Polityka Energetyczna Polski do 2040 r. - Strategia Rozwoju Sektora PaliwowoEnergetycznego, Warszawa, Poland, 2019. Available online: https://www.gov.pl/web/aktywapanstwowe/zaktualizowany-projekt-polityki-energetycznej-polski-do-2040-r (accessed on 12 November 2020).

15. Kapłan R., Kopacz M., Economic conditions for developing hydrogen production based on coal gasification with carbon capture and storage in Poland, Energies - Electronic journal; ISSN 1996-1073. - 2020 vol. 13 iss. 19 art. no. 5074, pp. 1-20. DOI: 10.3390/en13195074.

16. Ministry of Culture and Environment. Polityka energetyczna Polski do 2030 roku. Warsaw, 2020. Available online: https://www.gov.pl/web/klimat/polityka-energetyczna-polski-do-2030-roku (accessed on 12 November 2020).

17. Tomasik M., Knaga J., Lis S., Gliniak M.: Analysis of the effectiveness of the prototype PV tracking system, Applications of Electromagnetics in Modern Techniques and Medicine, PTZE 2018; 8503095, pp. 101-104.

18. Weather data and software for solar power investments. Reduce risks and maximise profitability of your solar energy assets. Solargis apps solargis.info. Available online: https://solargis.com/ (accessed on 10 November 2020).

19. National Fund for Environmental Protection and Water Management Prosument-dofinansowanie mikroinstalacji OZE. Available online: http://nfosigw.gov.pl/oferta-finansowania/srodki-krajowe/programypriorytetowe/prosument-dofinansowanie-mikroinstalacji-oze/ (accessed on 19 November 2020).

20. Institute, I. of E.P.-N.R. CO2, SO2, NOx, CO and total dust EMISSION RATIOS FOR ELECTRICITY based on the information contained in the National Database of Greenhouse Gas Emissions and other Substances for 2018.

21. Office for Energy Regulation Raport - zbiorcze informacje dotyczace wytwarzania energii elektrycznej z odnawialnych źródeł energii w małej instalacji (art. 17 ustawy o odnawialnych źródłach energii), Warsaw, April 2020. Available online: https://bip.ure.gov.pl/bip/o-urzedzie/zadania-prezesa-ure/raport-oze-art-17 ustaw/3556,Raportzbiorcze-informacje-dotyczace-wytwarzania-energii-elektrycznej-z-odnawial.html (accessed on 13 November 2020).

22. Kowalski W.,IEO Instytut Energetyki Odnawialnej, Autorski wskaźnik koniunktury rynku fotowoltaicznego. Available online: https://ieo.pl/pl/indeks-pv (accessed on 13 November 2020). 
23. Ministry of Development. Typical Reference Year (Dane do obliczeń energetycznych budynków). Available online: https://www.gov.pl/web/fundusze-regiony/dane-do-obliczen-energetycznych-budynkow (accessed on 13 November 2020).

24. The World Bank, Source: Global Solar Atlas 2.0, Solar resource data: Solargis. Available online: https://globalsolaratlas.info/map (accessed on 1 November 2020).

25. Kreft, W., Filipowicz, M. and Żołądek, M. Reduction of electrical power loss in a photovoltaic chain in conditions of partial shading. Optik 2020, vol. 202, DOI: 10.1016/j.ij-leo.2019.163559.

26. Calise, F., Figaj, R.D. and Vanoli, L. Energy performance of a low-cost Pho-toVoltaic/Thermal (PVT) collector with and without thermal insulation. IOP Conference Series: Earth and Environmental Science, 2019, vol. 214, DOI: 10.1088/1755-1315/214/1/012116.

27. Burgio, A., Menniti, D., Sorrentino, N., Pinnarelli, A. and Leonowicz, Z. Influence and impact of data averaging and temporal resolution on the assessment of energetic, economic and technical issues of hybrid photovoltaic-battery systems. Energies, 2020, vol. 13, No. 2, DOI: 10.3390/en13020354.

28. Zdyb, A. and Gulkowski, S. Performance assessment of four different photovoltaic technologies in Poland. Energies, 2020, vol. 13, No. 1, DOI: 10.3390/en13010196.

29. Olczak, P., Kryzia, D., Pepłowska, M. and Olek, M. Influence of Inclina-tion Angle and its Adjustment Time on Insolation of Collector or Photovoltaic Panel. District Heating, Heating, Ventilatio, 2018, vol. 49, No. 12, pp. 506509.

30. Zamasz K., Kapłan R., Kaszyński et al., An analysis of support mechanisms for New CHPs: the case of Poland, Energies, 2020, vol. 13 iss. 21 art. no. 5635, pp. 1-18.DOI: 10.3390/en13215635.

31. Żołądek, M., Filipowicz, M., Sornek, K. and Figaj, R.D. Energy per-formance of the photovoltaic system in urban area - Case study. IOP Conference Series 2019: Earth and Environmental Science, DOI: 10.1088/17551315/214/1/012123.

\section{Funding}

Not applicable.

\section{Author information}

Affiliations

AGH University of Science and Technology, Faculty of Management, Gramatyka 10, 30-059 Krakow, Poland

Mariusz Niekurzak, Ewa Kubińska-Jabcoń

\section{Contributions}

$\mathrm{MN}$ is the principal author of this paper. EKJ has contributed with ideas and discussion to the paper, as well as editing. All authors read and approved the final manuscript.

Corresponding author

Correspondence to Mariusz Niekurzak e-mail: mniekurz@zarz.agh.edu.pl

\section{Ethics declarations}


Ethics approval and consent to participate

Not applicable.

\section{Consent for publication}

Not applicable.

\section{Competing interests}

The authors declare that they have no known competing financial interests or personal relationships that could have appeared to influence the work reported in this paper.

\section{Acknowledgements}

Not applicable. 
Figures

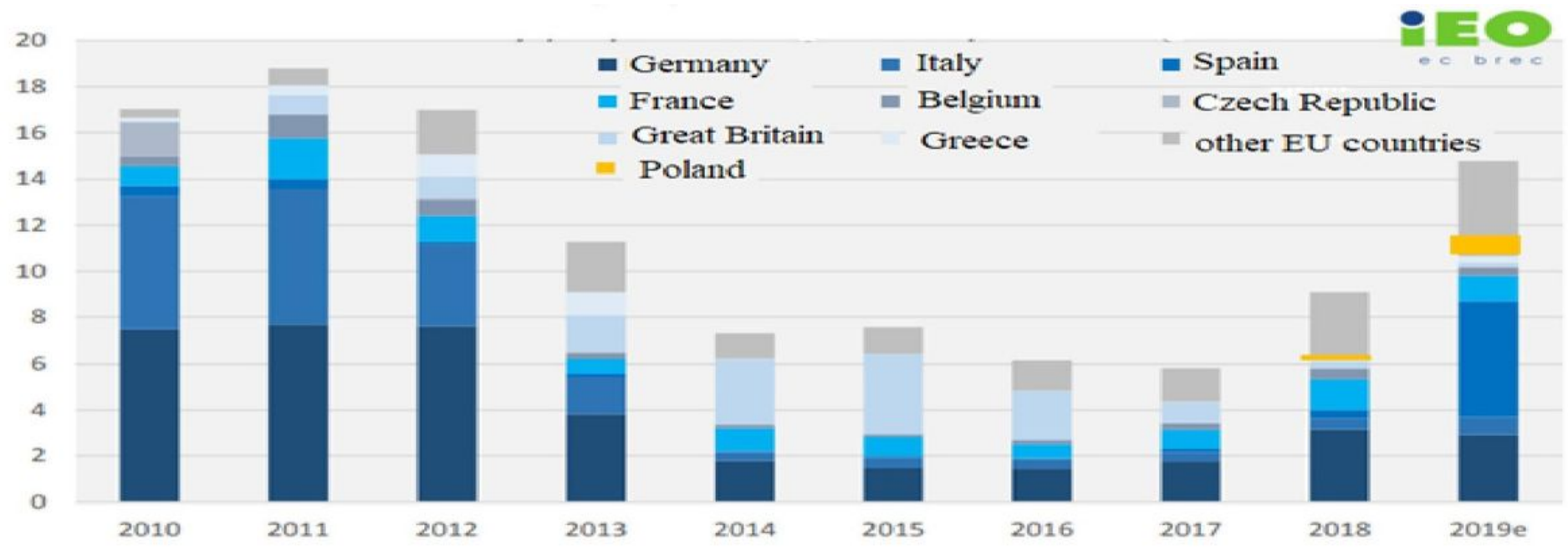

\section{Figure 1}

Annual increase in the new solar collectors capacity in EU countries [9].

(\%)

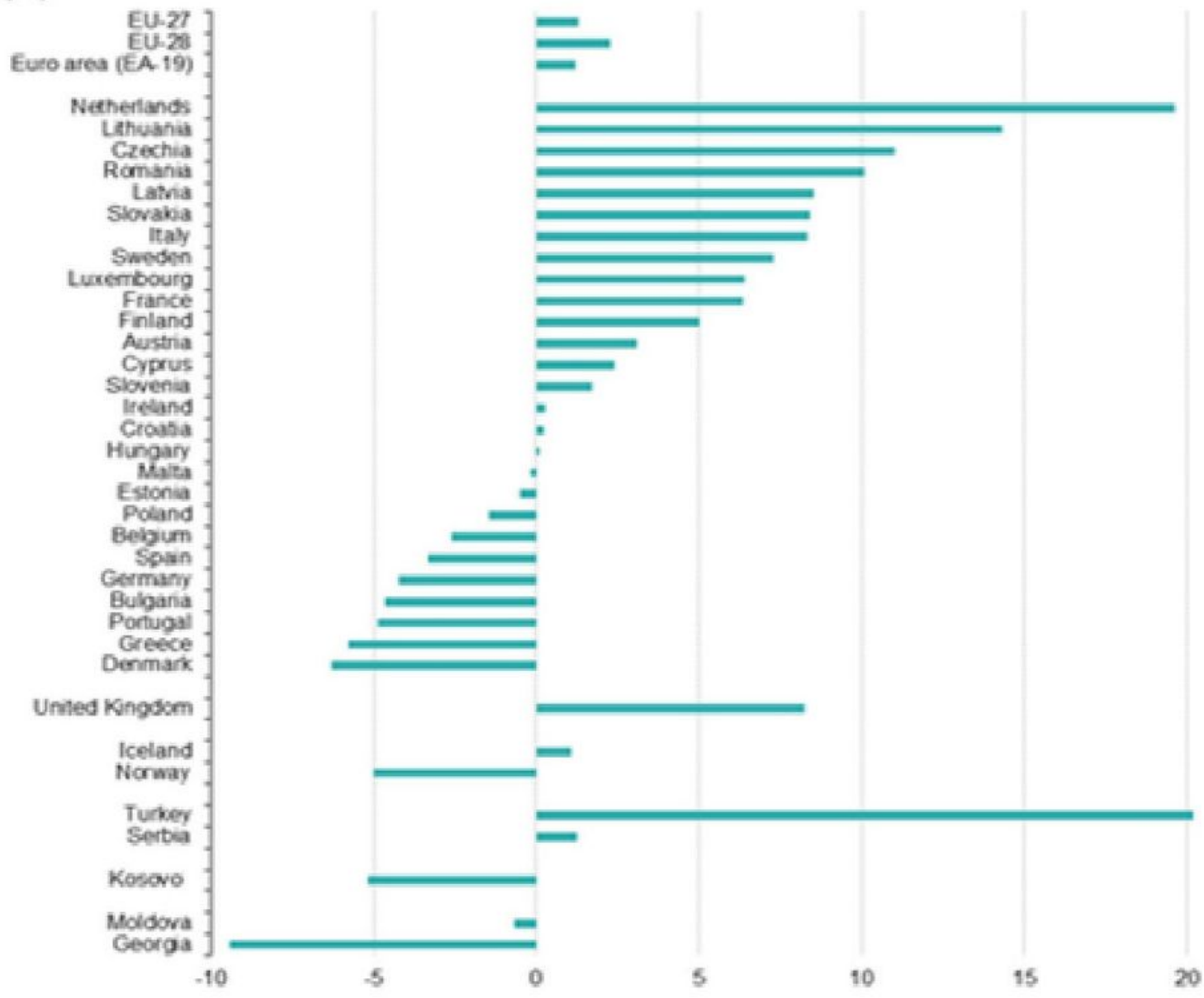

Figure 2 
Change in electricity prices for household consumers compared with previous year's same semester, second half of 2019 [3].

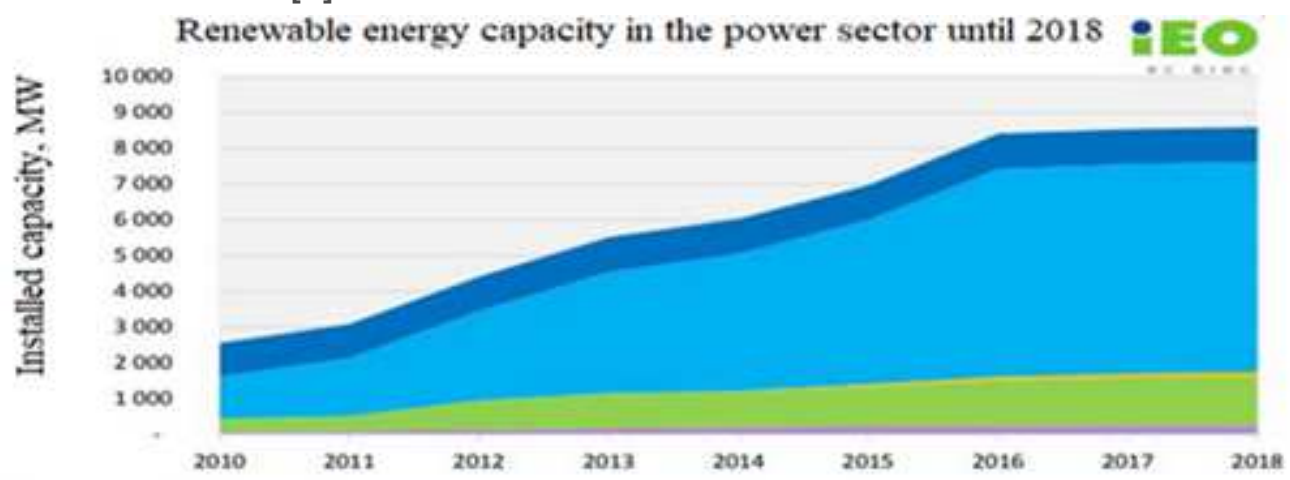

= biogas $=$ biomass $=$ solar collectors $=$ wind power plant $=$ hydroelectric power stations

\section{Figure 3}

Installed capacity in RES installations for electricity generation. Study of IEO based on the data of the Office for Energy Regulation [21].

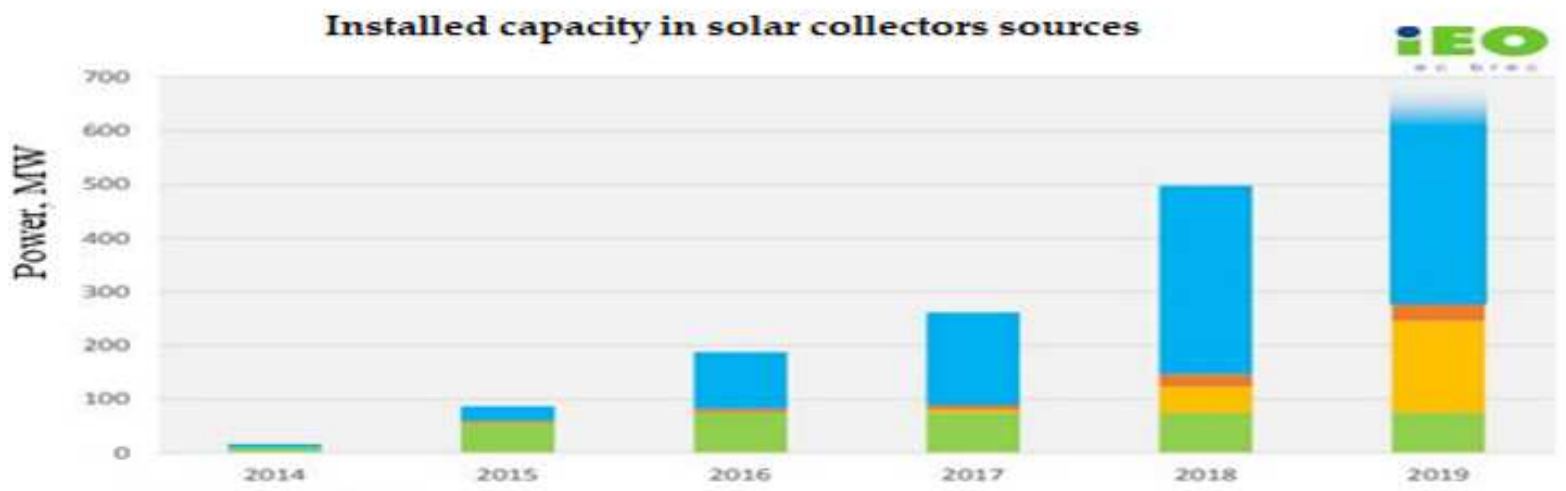

- solar collectors installations, MW

- small solar collectors installations, MW

- solar collectors installations that have won RES auctions and have alreadv benn completed, MW

- solar collectors instalations $>500 \mathrm{~kW}$ that were built by 2016 , MW

\section{Figure 4}

The installed capacities in solar collectors installations in Poland (as of April 2019) [21]. 


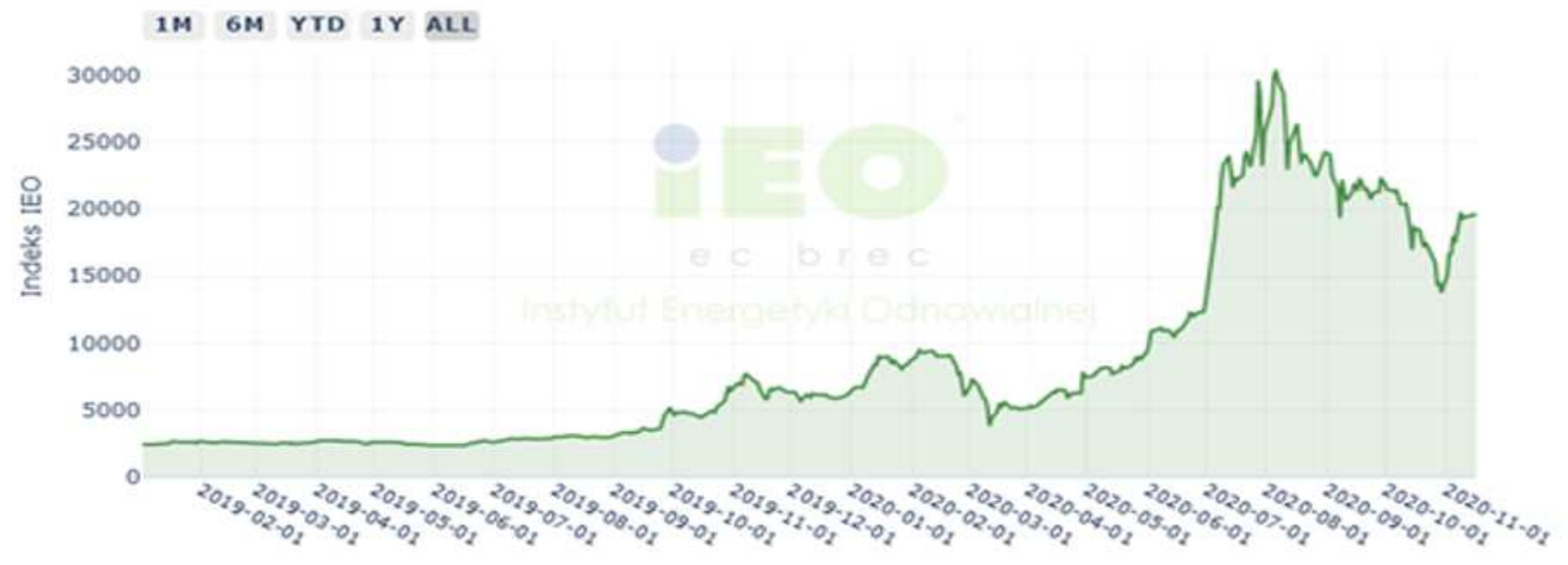

\section{Figure 5}

The indicator of the economic situation of the solar collectors market in Poland [22].

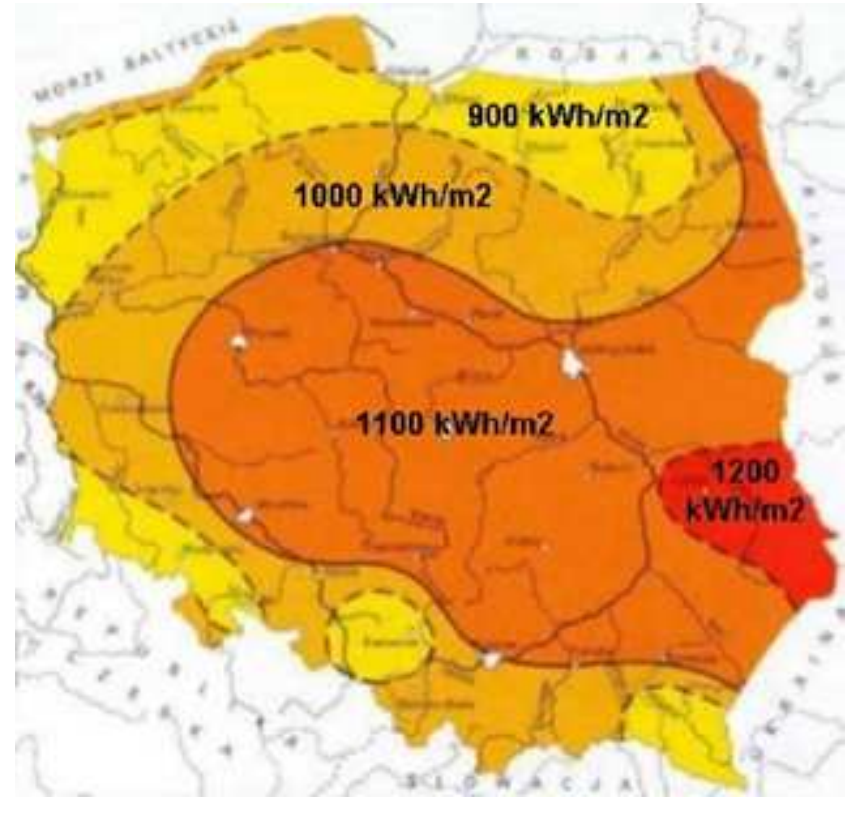

Figure 6

Map of average insolation values [24]. Note: The designations employed and the presentation of the material on this map do not imply the expression of any opinion whatsoever on the part of Research Square concerning the legal status of any country, territory, city or area or of its authorities, or concerning the delimitation of its frontiers or boundaries. This map has been provided by the authors. 

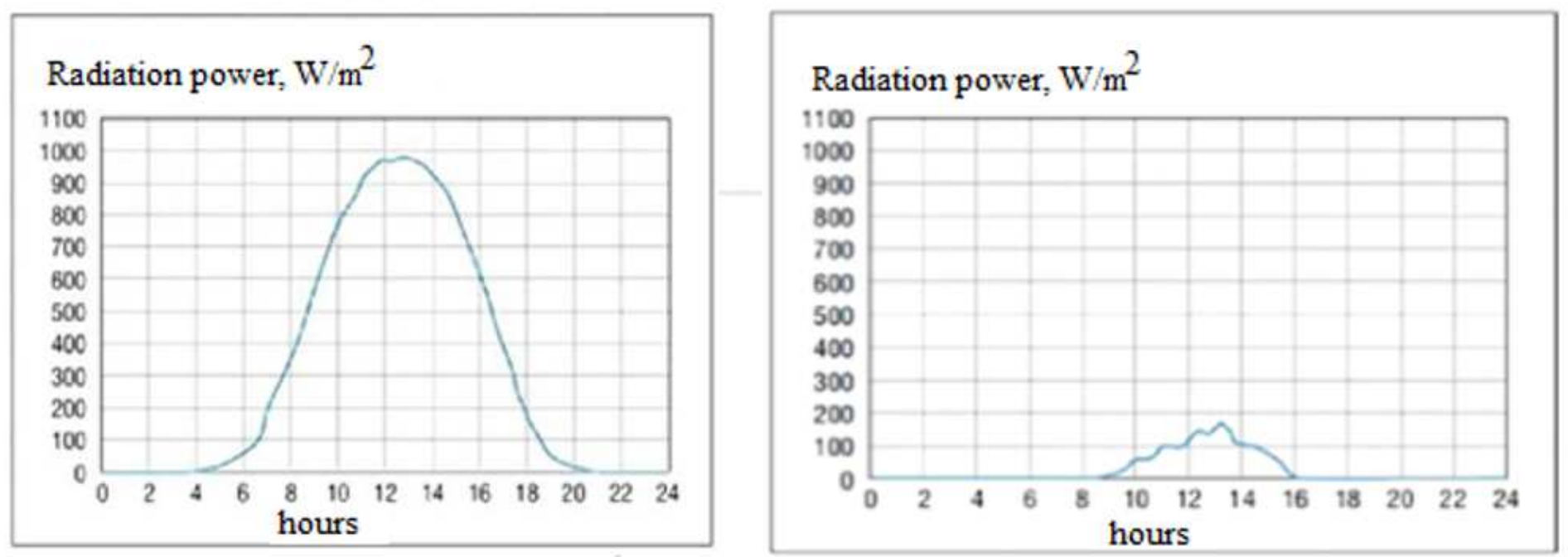

Figure 7

Daily radiation power in Poland: a) on a cloudless day in June, b) on a cloudy day in December [18].

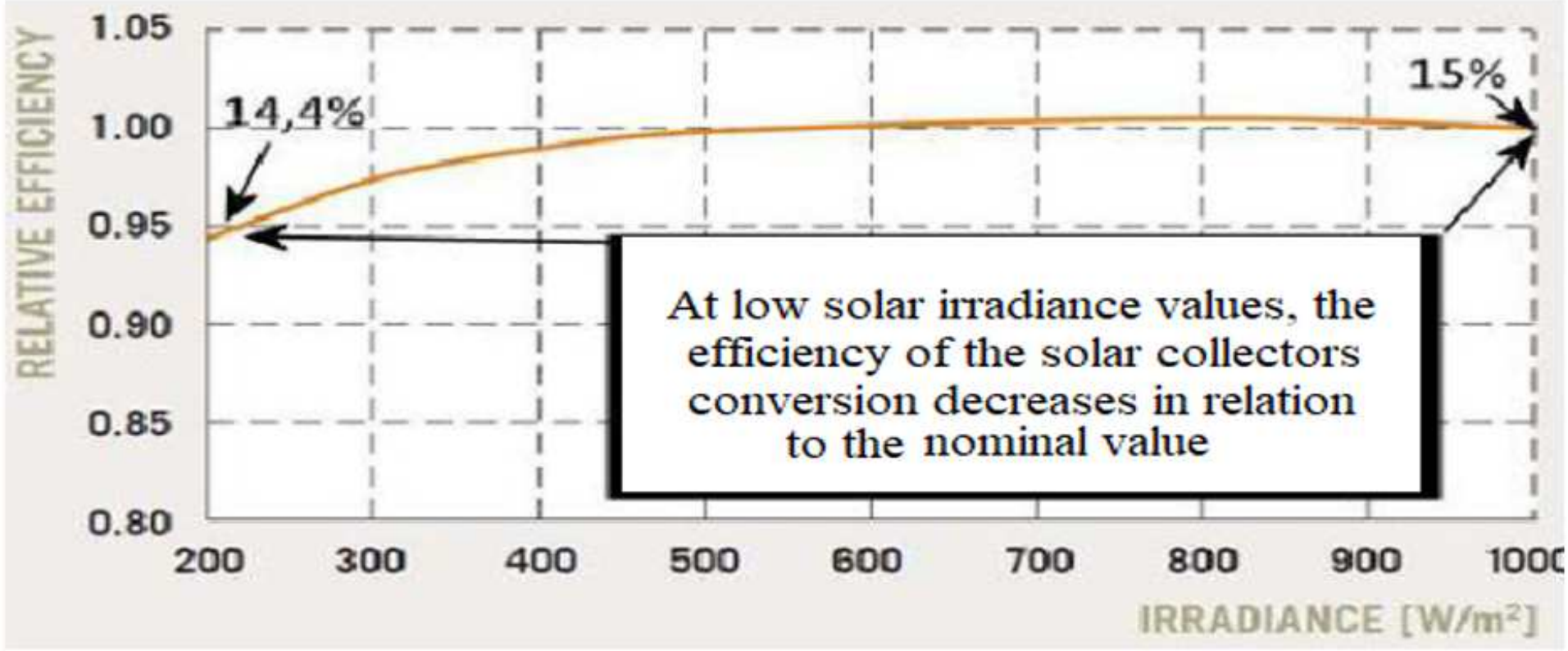

Figure 8

Change in efficiency of the solar collectors depending on the intensity of solar radiation [26]. 
EUR

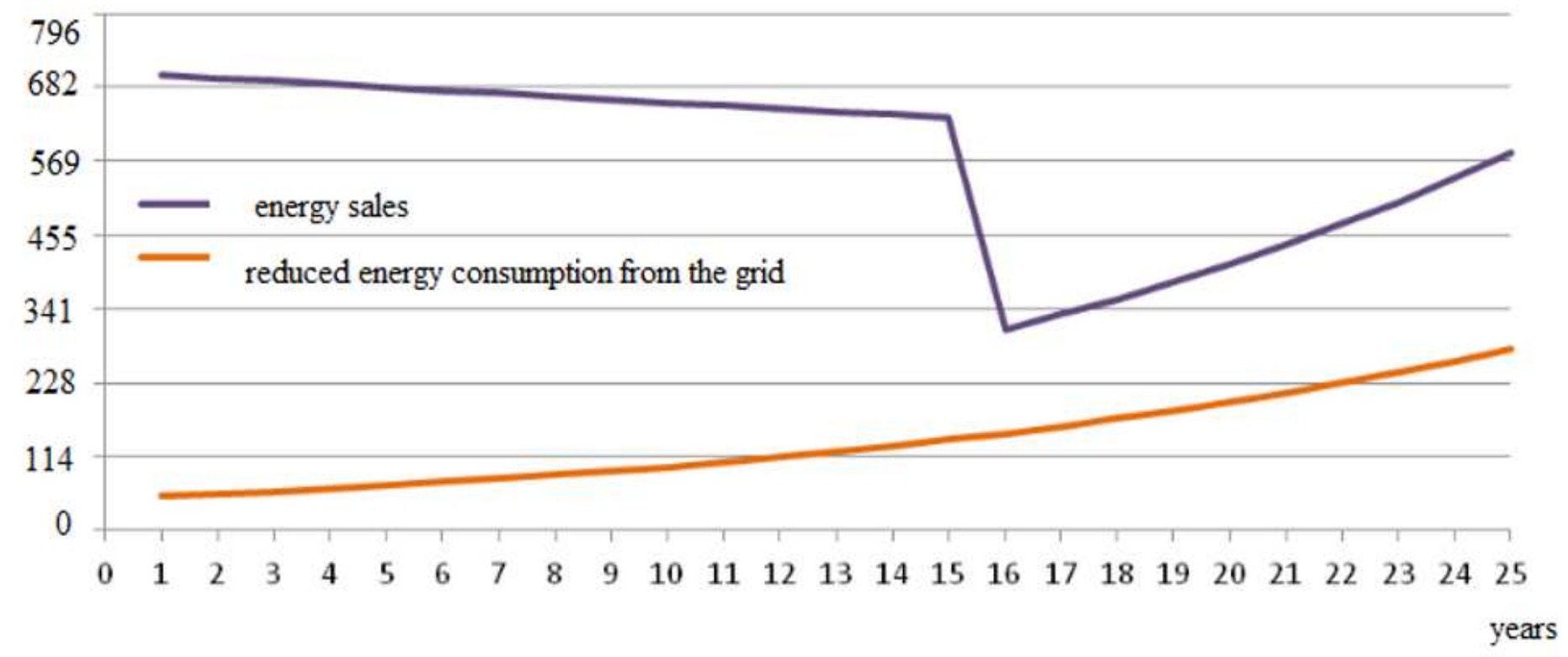

Figure 9

Revenues from the sale of energy generated in the solar collectors system and from reduced consumption of energy from the grid. Source: own study.

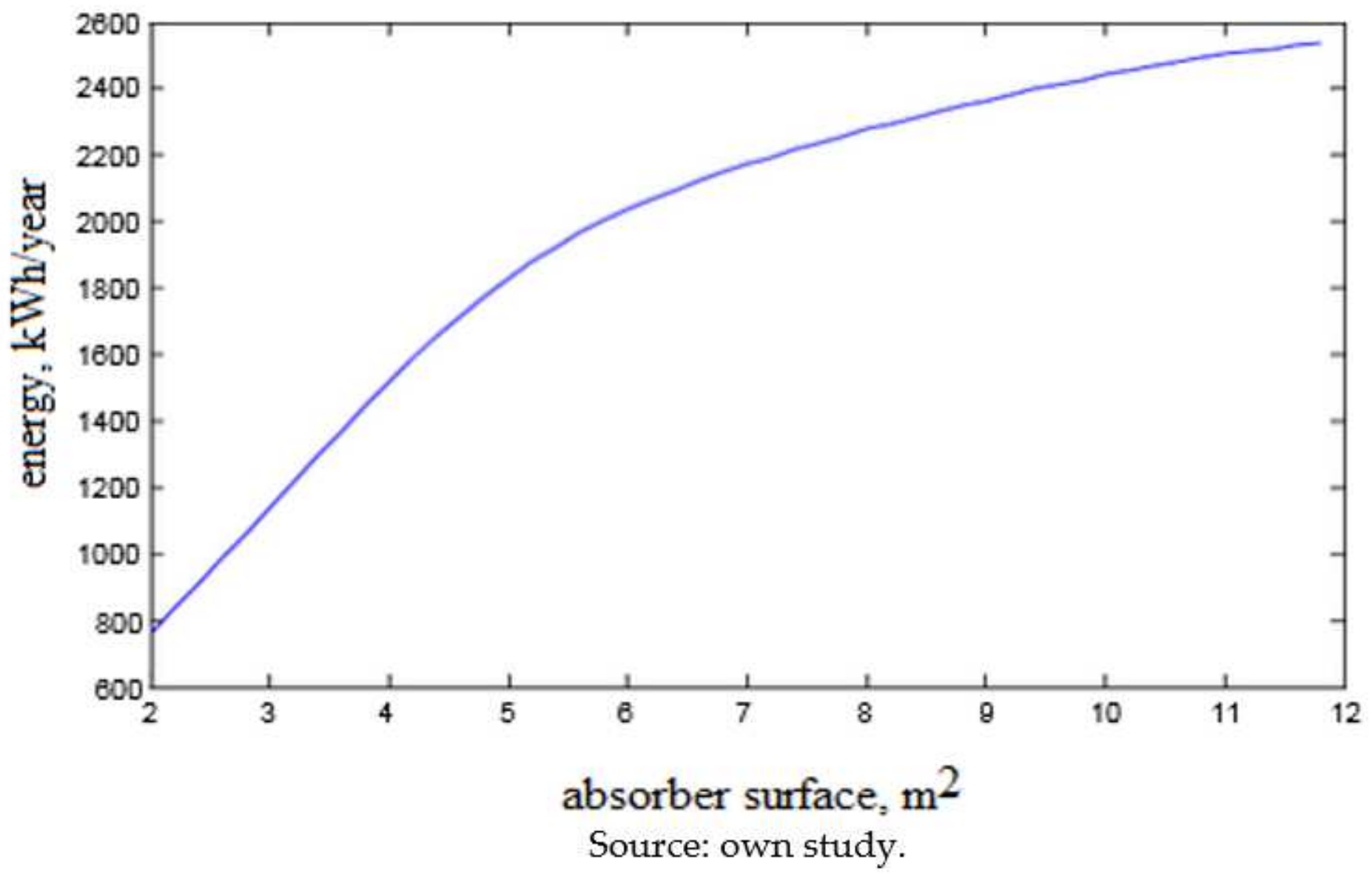

Figure 10 
Dependence of annual corrected solar yields for the analysed system as a function of the absorber area.

(2) effective solar yields, $\mathrm{kWh} /$ year

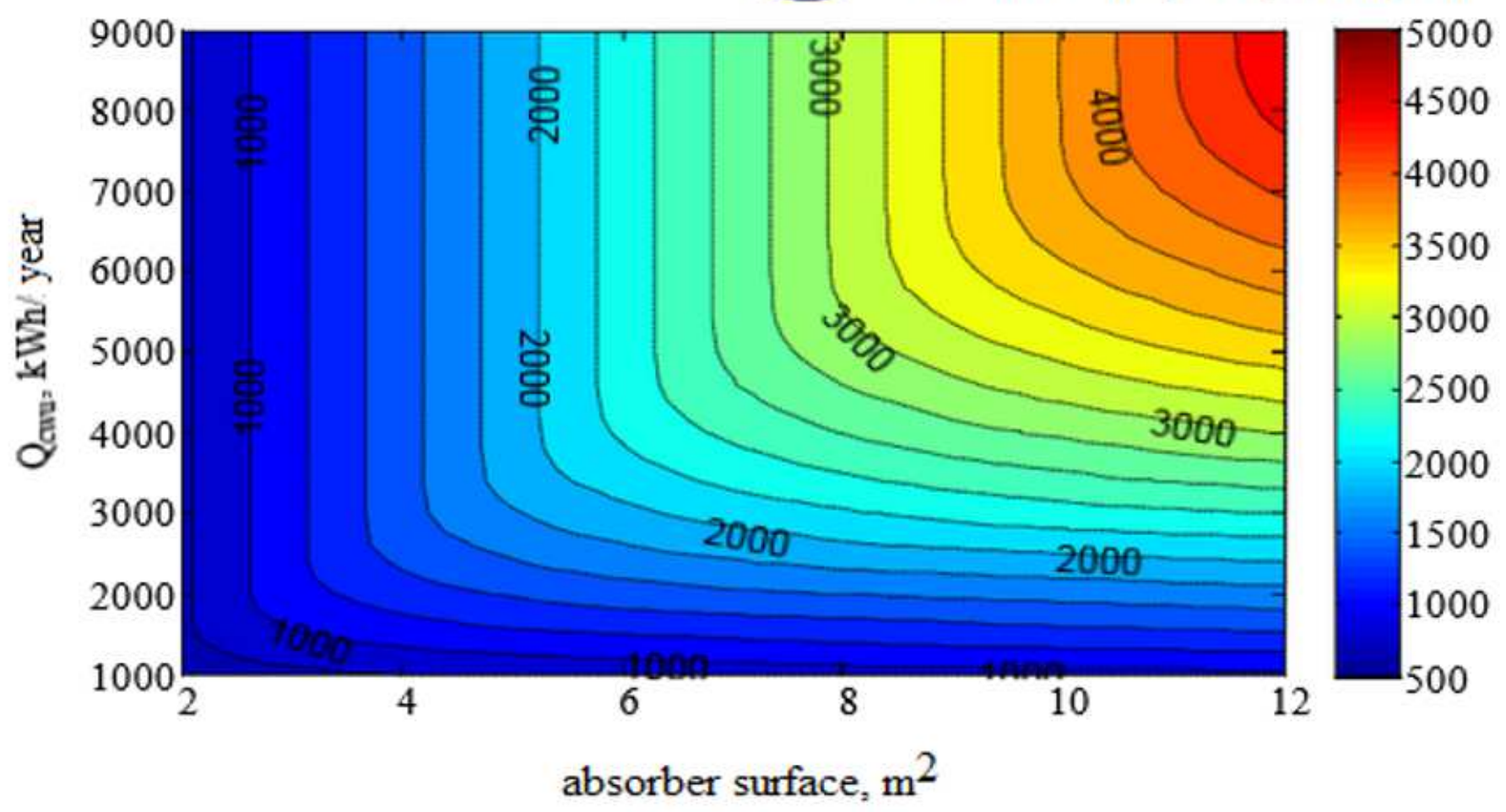

Figure 11

Diagram of examples of effective solar yields as a function of the absorber area and heat demand for hot water preparation. 